\title{
9. klassi õpilaste huvi eri kontekstis esitatud loodusteaduslike teemade õppimise vastu ja motivatsioon õppida loodusteadusi
}

\author{
Moonika Teppo ${ }^{\text {a1 }}$, Helen Semilarskia, \\ Regina Soobard ${ }^{a}$, Miia Rannikmäe ${ }^{a}$ \\ ${ }^{a}$ Tartu Ülikooli loodusteadusliku hariduse keskus
}

\begin{abstract}
Annotatsioon
Viimaste aastate uuringute tulemused näitavad, et õpilased hindavad üha enam loodusainete õppimise vajalikkust, kuid endiselt on teemavaldkondi, mille õppimise vastu nad huvi ei tunne, kuna need on vähe seotud nende igapäevaelu või sotsiaalse keskkonnaga. Vähe on aga uuritud seda, kuidas loodusteaduslike õppeainete sisu esitamine eri kontekstis mõjutab õpilaste huvi õppekavaga kindlaks määratud teemade õppimise vastu. Artikli põhieesmärk on välja selgitada, millises kontekstis esitatud loodusteaduslike teemade õppimisest on 9. klassi õpilased $(N=848)$ huvitatud ning milline on õpilaste motivatsioon õppida loodusteaduslikke õppeaineid. Andmeid koguti katsetatud ja valideeritud kompleksinstrumendiga. Andmete analüüsimiseks kasutati nii peakomponentide kui ka klasteranalüüsi meetodeid. Leitud dimensioonid kirjeldavad õpilaste huvide kontekstuaalset iseloomu. K-keskmiste klasteranalüüsi tulemusena eristus nelja loodusaine sees kolm (kokku 12) õpilaste motivatsiooniprofiili, mis võimaldavad kirjeldada põhikooli lõpuklasside õpilaste huvisid ja motivatsioonilisi suundumusi loodusainete õppimisel. Õpilaste motivatsioon õppida loodusaineid on üldiselt suur ja seda nii tüdrukutel kui ka poistel.
\end{abstract}

Võtmesõnad: loodusteaduslikud teemad, huvi, kontekst, motivatsiooniprofiilid

\section{Sissejuhatus}

Tänapäeva ühiskond vajab aktiivseid kodanikke, kes väärtustavad haridust, sealhulgas loodusteaduslikke õppeaineid. Kui loodusteaduslike õppeainete õppimine on õpilaste jaoks tähenduslik, siis nad mõistavad nende ainete

Loodusteadusliku hariduse keskus, Tartu Ülikool, Vanemuise 46, 51014 Tartu; moonika.teppo@ut.ee 
tundides omandatud teadmiste ja oskuste tähtsust ning oskavad võtta seda elukutse valikul arvesse. PISA 2006 rahvusvahelise võrdlusuuringu tulemused näitavad, et vaatamata Eesti õpilaste headele või väga headele tulemustele loodusteadustes ning nende huvile loodusteadusi õppida soovis neist vaid väike osa (16\%) endale tulevikus rakendust leida loodusteadustega seotud erialadel (OECD, 2007). PISA 2006. ja 2015. aasta tulemuste võrdlusest selgub, et statistiliselt olulisel määral on kasvanud $(7,8 \%)$ nende õpilaste osakaal, kes on valmis valima loodusteadustega seotud elukutse (OECD, 2016; PISA 2015 Eesti tulemused, 2016). See on küll ühelt poolt positiivne tendents, kuid teiselt poolt on oluline sellist taset hoida, ajakohastades loodusteaduslike õppeainete õpetamist koolis.

Soov edasi õppida loodusteaduste valdkonnas on seotud otseselt õpilaste huviga konkreetsete õppeainete vastu ja sellest tuleneva motivatsiooniga. Kui õpilane on koolis loodusteaduslike õppeainete õppimisest huvitatud, siis suure tõenäosusega jätkab ta ka õpinguid kõrgkoolis ja valib loodusteadusliku karjääri (DeWitt \& Archer, 2015). Huvi olemasolu korral on õpilased motiveeritumad omandama loodusteaduslike õppeainete tundides kujundatavaid teadmisi ja oskusi. Veelgi enam, ka loodusteaduslikke õppeaineid õppides peaks õpilastes kujunema valmisolek ja oskused elukestvaks õppeks. Loodusteaduslike õppeainete õppesisu kõrval omandavad positiivse õpimotivatsiooniga õpilased ka oskuse luua interdistsiplinaarseid seoseid eri õppeainete ja igapäevaelu vahel, lahendada probleeme ja võtta vastu põhjendatud otsuseid nii üksinda kui ka meeskonnas (Eesti elukestva õppe strateegia 2020, 2014).

Kui õpilase motivatsioon õppida loodusteaduslikke õppeaineid on positiivne, siis ta tunneb õpitava vastu huvi ning näeb võimalusi rakendada õpitavat oma igapäevaelus (sisemine motivatsioon). Kui aga õpilane õpib ainult kohusetundest või näiteks vanemate survel või hinde pärast (väline motivatsioon), siis võib kohustuste lõppedes huvi õppimise vastu väheneda või hoopis kaduda. Neid Eesti 15aastaseid õpilasi, keda loodusteaduste õppimine ei huvita, on PISA 2015 uuringu andmetel 37\% vastanutest (tüdrukuid rohkem kui poisse), seega kuulub nende hulka peaaegu iga neljas õpilane (OECD, 2016; PISA 2015 Eesti tulemused, 2016). Seetõttu on vaja leida võimalusi, kuidas tekitada ja suurendada nende õpilaste õpihuvi, kellel see puudub või on minimaalne (Brophy, 2010).

Igapäevaeluga seotud (sh personaalseid) kontekste on kasutatud mitmes suuremahulises projektis (PROFILES, ESTABLISH, ChiK). Samas puuduvad uuringud selle kohta, millised kontekstid on õpilaste jaoks huvitavamad, lähtudes kooli õppekava loodusteaduslikest teemadest. Erinevalt varasematest uurimustest, kus on uuritud õpilaste üldist õpihuvi 
või huvi loodusteaduslike teemade õppimise vastu (Schreiner \& Sjøberg, 2007; Teppo, 2004; Teppo \& Rannikmäe, 2008), on siinse artikli põhieesmärk määrata teaduskirjandusele tuginedes kindlaks kontekstipõhise huvi dimensioonid ning uurida, milline on loodusteaduslike õppeainete puhul õpilaste huvi nendele dimensioonidele vastavate kontekstide vastu. Eesmärgist lähtudes sõnastati järgmised uurimisküsimused.

- Millised kontekstid pakuvad ühe ja sama õppekavaga määratud loodusteadusliku teema piires õpilastele rohkem huvi?

- Milliseid soolisi erinevusi esineb õpilaste huvis ja motivatsioonis õppida loodusaineid?

- Milliseid õpilaste motivatsiooniprofiile on võimalik eristada ja kuidas need suhestuvad õpilaste huvidega?

\section{Teoreetiline ülevaade}

\section{Huvi mõiste}

Õpilaste huvi loodusteaduste õppimise vastu on oluline uurimisobjekt nii loodusteaduslikus hariduses kui ka poliitilisel tasandil. Huvi on üks õppimise motivaatoreid, mida peetakse sisemise motivatsiooni osaks (Cheng \& Yeh, 2009). Huvi on võimalik määratleda ka kui protsessi, mis soodustab õppimist ja saavutusi (Chen \& Shen, 2004). Renninger (2000) on oma uurimuses osutanud, et kui on huvi millegi vastu, siis hakatakse otsima vastust uudishimu tekitanud küsimusele (nt Miks tulevad ussid pärast vihmasadu välja?). Laiemas kontekstis tähendab huvi mingite objektide eelistamist teistele (Prenzel, 1992) ja ka õppimiseks valmisolekut (Hidi \& Renninger, 2006; Silvia, 2006).

Üks viise uurida huvi on isiku ja objekti vaheline huvi teooria (personobject theory of interest) (Krapp, 1999, 2002, 2005), mille järgi on huvi spetsiifiline interaktsioon isiku ja objekti vahel ning see kätkeb nii emotsionaalseid kui ka kognitiivseid kontrollimehhanisme (Krapp, 2005). Mõiste objekt võib aga viidata konkreetsele asjale, valdkonnale, sündmusele või abstraktsele ideele (Krapp \& Prenzel, 2011). Hariduslikus kontekstis on Krappi huvi-teooria järgi indiviidiks õpilane ning objektiks õppematerjal või -tegevus (Hidi, Renninger, \& Krapp, 2004; Krapp, Hidi, \& Renninger, 1992). Kokkuvõtvalt, Hidi (2001) järgi saab huvi tekitada siis, kui indiviidil (õpilasel) on vastastikmõju keskkonnaga. Siinses artiklis käsitletakse õpilaste huvi konkreetsete loodusteaduslike teemade (objekti) õppimise vastu.

Huvi uurimisel on sageli eristatud individuaalset ja situatsioonilist huvi (Dohn, 2011; Hidi, 1990, 2000; Krapp \& Prenzel, 2011; Renninger, 1990, 2000; Schraw \& Lehman, 2001). Individuaalne huvi viitab püsivale, 
suhteliselt pikaaegsele teema eelistusele, mis kujuneb välja aeglaselt ning on seotud teadmiste suurema omandamise ja väärtustamisega. Seevastu situatsioonilise huvi kutsuvad esile teatud keskkonnategurid või -tingimused, mis kajastavad kohest afektiivset reaktsiooni (tundepurset) ning mille tulemusena võib huvi jääda püsima või kaduda (Hidi \& Harackiewicz, 2001). Uuringud on näidanud, et nii individuaalne kui ka situatsiooniline huvi viivad selleni, et õpilane on ülesande lahendamise nimel valmis rohkem pingutama, püsib paremini ülesande lahendamise juures ning on tähelepanelikum (Ainley, Hidi, \& Berndorff, 2002; Hidi \& Renninger, 2006). Praeguses uurimuses kasutatakse situatsioonide elemente kontekstide sõnastamisel.

\section{Huvi loodusteaduslike teemade õppimise vastu}

Õpilaste huvi uurimisele on lähenetud kas ühe loodusaine spetsiifiliselt, nt füüsikas (Badri, Al Mazroui, Al Rashedi, \& Yang, 2016; Häussler \& Hoffmann, 2002; Reid \& Skryabina, 2003; Trumper, 2006; Walper, Pollmeier, Lange, Kleickmann, \& Möller, 2016), bioloogias (Baram-Tsarabi \& Kaadni, 2009; Baram-Tsarabi, Sethi, Bry, \& Yarden, 2010; Gardner \& Tamir, 1989; Hagay et al., 2013; Hong, Shim, \& Chang, 1998), keemias (Alebiosu, 2006) ja geograafias (earth science) (Betzner \& Marek, 2014; Harp \& Mayer, 1997), või loodusaineteüleselt (Dawson, 2000; Christidou, 2006; Lavonen et al., 2008; Teppo \& Rannikmäe, 2008). Õpilaste teadmiste ja oskuste testimise kõrval on loodusainete õppimisega seotud huve ja hinnanguid vähemal määral uuritud ka rahvusvaheliste võrdlusuuringute, nagu TIMSSi ja PISA raames. Näiteks ilmnes PISA 2015 uuringust, et Eesti 15aastased poisid on statistiliselt olulisel määral rohkem huvitatud liikumist ja jõudu ning energiat ja selle muundumist käsitlevatest teemadest, tüdrukud aga tervishoiuvaldkonnast (PISA 2015 Eesti tulemused, 2016).

Kõige informatiivsemaks on osutunud mahukas rahvusvaheline uuring ROSE (The Relevance of Science Education), milles keskenduti 15-16aastaste õpilaste huvide, hinnangute ja kogemuste uurimisele loodusteaduste ja tehnoloogia valdkonnas (Schreiner \& Sjøberg, 2004, 2007; Sjøberg \& Schreiner, 2008). Uuringu tulemustest ilmnesid nii riikidevahelised kui ka soolised erinevused. Näiteks andsid arengumaade õpilased kõrgemaid hinnanguid loodusainete meeldivusele ning nende huvi erinevaid loodusteaduslikke teemasid õppida oli suurem kui sama vanadel arenenud riikide õpilastel. Siinkohal tuleb mainida, et uuringul ROSE puudub valideeritud teoreetiline raamistik. See uuring võimaldab küll anda vastuseid üksikväidetele, aga nende usaldusväärsus kooli õppekava kontekstis vajab edasist uurimist. ROSE’i instrumendi kasutamise põhjal on tehtud mitmeid 
järeldusi, nt tüdrukud on enim huvitatud oma tervisega ja poisid tehnoloogiaga seonduvatest teemadest, kuid siingi olid küsimused juba alguses sõnastatud soospetsiifiliselt.

Lavonen jt (2008) on ROSE'i instrumenti kasutades leidnud, et Soome 15-16aastastele õpilastele kõige huvipakkuvamad teemad seostusid astronoomiaga (tähed, planeedid, universum). Kõige vähem pakkusid õpilastele huvi aga seadmete ehitus ja tööpõhimõtted, tuumaenergia ning satelliidid, seevastu info- ja kommunikatsioonitehnoloogiaga seotud tehnilised vahendid (nt mobiiltelefonid ja arvutid) tundusid neile huvitavad. Samuti selgus uuringust, et huvi tekkimist mõjutab ka kontekst: personaalses või sotsiaalses võtmes esitatud teemad olid enam huvipakkuvad. Sarnastele järeldustele on jõudnud ka praeguse uurimuse autorid, kasutades ROSE' $\mathrm{i}$ instrumendi modifitseeritud/laiendatud üksikosi (Teppo, 2004; Teppo \& Rannikmäe, 2008).

Varasemad uuringud on näidanud, et õpilaste huvi loodusteaduslike teemade õppimise vastu on muutuv ning sõltub mitmetest teguritest, nt ópilaste eelteadmistest ja vanusest, teema tajutavast raskusest ja seotusest igapäevaeluga. Näiteks kui ópilastele õpetada ainult uut ainesisu, jättes arvestamata eelteadmised ja igapäevaelulise konteksti, siis see vähendab nende huvi teema vastu (Fensham, 2004; Osborne \& Collins, 2001; Salta \& Tzougraki, 2004). Ka vanuse suurenemisega väheneb õpilaste huvi loodusteadusi õppida (Dawson, 2000; Osborne, Simon, \& Collins, 2003; Potvin \& Hasni, 2014; Walpner et al., 2016). Lisaks võib soodustada huvi kahanemist loodusteaduslike õppeainete eraldi õpetamine (Reid \& Skryabina, 2003) ning abstraktsete, teoreetiliste teemade intensiivsem käsitlemine alates põhikooli 7. klassist, seda eriti just füüsika ja keemiaga seonduvate teemade puhul (Walpner et al., 2016). Seega tuleks loodusainete õpetamisel arvestada üha enam sellega, mis pakub õpilastele huvi ning mida nad oluliseks (relevantseks) peavad.

Termini relevantsus kohta on mitmeid definitsioone ja käsitlusi. Näiteks seostatakse seda loodusteaduste kontekstis kõige enam huviga (Matthews, 2004; Ramsden, 1998). Praeguses uurimuses on instrumentide koostamisel aluseks võetud Van Aalsvoorti (2004) neli dimensiooni: personaalne relevantsus, mis rõhutab loodusteaduslike ainete tundide relevantsust õppijast lähtudes; professionaalne relevantsus, mis eeldab, et loodusteaduslike ainete tundides tutvustatakse erinevaid elukutseid ja loodusteaduslike teadmiste osa elukutsevalikul; sotsiaalne relevantsus, mille tingimuse täitmisel tagatakse arusaam teaduse osast sotsiaalsete probleemide lahendamisel; personaalne/sotsiaalne relevantsus, mis eeldab, et loodusteaduste tunnid aitavad õpilastel kujuneda vastutustundlikuks ühiskonna liikmeks. Õppija seisukohast on olulisim personaalne relevantsus ehk see, mis pakub õpilasele isiklikku huvi (Brophy, 2010). 


\section{Loodusteaduste õppimisega seotud õpimotivatsioon}

Huvi mõistega on väga tihedalt seotud motivatsiooni mõiste. Motivatsiooni defineeritakse sotsiaal-kognitiivse teooria seisukohast kui sisemist seisundit, mis soodustab, suunab ja hoiab eesmärgipärast käitumist (Brophy, 2010). Motivatsiooniteooriate kohaselt kutsuvad motivatsiooni kui psühholoogilise seisundi esile indiviidi füsioloogilised (vee, toidu ja unega seotud), tunnustus-, ühtekuuluvus- jm vajadused. Motivatsiooni võib jagada väliseks ja sisemiseks motivatsiooniks (Hidi \& Harackiewicz, 2000; Lepper, Corpus, \& Iyengar, 2005). Välise motivatsiooni ajendiks on ootus tasu või tunnustuse järele, kuid ka hirm karistuse või negatiivse tagasiside ees (Deci \& Ryan, 2002; Larson, 2000). Sisemine motivatsioon tekib siis, kui õpilasel on sisemine tahe teha mõnd tegevust - see pakub talle huvi ja naudingut (Reeve \& Jang, 2006; Ryan \& Deci, 2000). Seega on sisemise motivatsiooni kujunemise eeldus huvi konkreetse tegevuse või teema vastu (Hidi, 2000; Locke \& Latham, 2006; Maehr \& Meyer, 1997; Ramsden, 1998).

Sisemist motivatsiooni ja individuaalset huvi on käsitletud küll eraldi konstruktidena, kuid samas ennustavad nad sarnaseid tulemusi, näiteks soodustavad sügavat õppimist või pingutusi, mida õpilane teeb oodatava tulemuse saavutamiseks (Hidi, 2000). Seevastu situatsiooniline huvi on sarnasem välise motivatsiooniga, kuna huvi kutsutakse esile väliste stiimulite mõjul ning see säilib lühikest aega ehk niikaua, kuni kestab stiimul (ibid.).

Õpilaste motivatsiooni uurimiseks on välja töötatud mitmeid instrumente, millest levinuimad on sisemise motivatsiooni mõõtmise instrument (Intrinsic Motivation Inventory, IMI) (Deci \& Ryan, 2015) ja loodusteaduste motivatsiooniküsimustik (Science Motivation Questionnaire, Science Motivation Questionnaire II, SMQ, SMQ II) (Glynn, Brickman, Armstrong, \& Taasoobshirazi, 2011; Glynn \& Koballa, 2006; Glynn, Taasoobshirazi \& Brickman, 2009). Kui esimesel juhul on instrumendi teoreetiline raamistik üles ehitatud enesemääratlusteooriale (Deci \& Ryan, 2000), siis teisel juhul põhineb see sotsiaal-kognitiivsel teoorial (Bandura, 2001). Kuigi kahe küsimustiku skaalad kattuvad sisemise motivatsiooni, enesetõhususe ja pingutuse osas suuresti, sisaldab loodusteaduste motivatsiooniküsimustik lisaks välise motivatsiooni skaalasid, nagu karjääri- ja hindemotivatsioon (Glynn et al., 2011). Praeguse uurimuse raames otsustati õpimotivatsiooni uurimiseks kasutada Deci ja Ryani (2015) väljatöötatud mõõteinstrumenti, mille eesmärk on hinnata õpilaste huvi (interest/enjoyment), pingutuse määra (effort/importance), väärtustamist (value/usefulness), survestamist (pressure/tension), seotust (relatedness), tajutud kompetentsust/enesetõhusust (perceived competence) ja autonoomiatunnet (perceived choice) seoses mingi tegevuse või õppeülesande sooritamisega. Siinjuures tuleb märkida, 
et huvi/meeldivuse alaskaala ennustab kõige enam õpilaste sisemist motivatsiooni, ülejäänud mängivad pigem teisejärgulist rolli, aidates säilitada sisemist motivatsiooni.

Eelnimetatud originaalinstrumendi kohandamisel saadi viie alaskaalaga versioon, millest on välja jäetud seotuse ja tajutud surve/pinge alaskaala, kuna need ja neis sisalduvad väited ei sobitunud uuringu lähteülesande ja eesmärgiga hinnata õpilaste motivatsiooni loodusteaduste kontekstis.

\section{Kontekstid loodusteaduslike teemade õppimisel}

Konteksti all mõistetakse kaasteksti, mis võimaldab sõna tähendust või sisu paremini mõista. Gilbert (2006) kirjeldab konteksti kui olukorda, mis annab tähenduse sõnadele ja lausetele, samuti tagab kontekst ,sidusa struktuuride tähenduse" uutele ideedele, mis paiknevad laiemas raamistikus. De Jong (2006) on defineerinud konteksti kui situatsiooni, mis aitab anda loodusteaduslike ainete tundides õpitavatele mõistetele, reeglitele, abstraktsetele teemadele tähendusrikast sisu. Mõlemal juhul käsitletakse konteksti kui ühte võimalust, mille kaudu saab tekitada õpilastes huvi loodusteaduslike õppeainete õppimise vastu, näidates loodusteaduslike teadmiste ja oskuste rakendatavust õpilaste jaoks relevantses ja tähendusrikkas igapäevaeluga seotud kontekstis (King, 2012; Pilot \& Bulte, 2006).

Peale personaalse (igapäevaelulise) konteksti eristavad mitmed autorid sotsiaalset, professionaalset või teaduslik-tehnoloogilist konteksti (Broman \& Parchmann, 2014; De Jong, 2006; Gilbert, Bulte, \& Pilot 2011; King, 2012). Siin võib näha sarnasust relevantsuse dimensioonidega (Van Aalsvoort, 2004).

Gilbert (2006) on loodusteaduslike õppeainete tundide puhul eristanud nelja tüüpi kontekste: kontekst kui mõistete vahetu rakendus (peale mõistete õpetamise tutvustatakse õpilastele ka teadusmõiste rakenduslikku sisu); kontekst kui mõistete ja rakendusviiside vastastikune seos (mõistele lähenetakse ekspertide, nt teadlase, arsti, juristi seisukohalt ning see loob olukorra, kus õpilane peab väärtustama ka sotsiaalset konteksti); kontekst kui personaalne tegevus (kontekst seostub kindla isiku või õpilase endaga); kontekst kui sotsiaalne situatsioon (kontekst, millel on ka kultuuriline tähendus, seostub probleemi olulisusega ühiskonnas). Siinses uurimuses eristatakse kolme konteksti kategooriat - ainesisu, teaduslik rakendamine ja sotsiaal-teaduslik probleem -, mis on loodud eelnimetatud autorite kontekstide jaotuste põhjal.

Kontekstide kasutamisel õppetöös on mitu eesmärki. Gilbert jt (2011) on osutanud, et kontekstide kasutamine võimaldab vähendada ülekoormatust 
õppekavades, muuta ainesisu vähem killustatuks ja õpetamist efektiivsemaks, näidates loodusteaduslike teadmiste ja oskuste tähtsust igapäevaelus. Eri kontekstide kasutamine õppetöös soodustab õpilaste huvi loodusteaduslike õppeainete õppimise vastu, sest õpilased näevad omandatud teadmiste ja oskuste kasulikkust nende endi igapäevaelus. Seeläbi suureneb ka õpilaste motivatsioon õppida loodusteaduslikke õppeaineid (Bennett, Lubben, \& Hogarth, 2007; Broman, Bernholt, \& Parchmann, 2015).

Konteksti esinemisvormid erinevad oma tähenduse, tähtsuse ja asjakohasuse poolest. Teaduskirjanduses kasutatakse selle väljendamiseks mõistet relevantsus (Levitt, 2001). Seejuures ei peeta silmas mitte ainult konteksti relevantsust, vaid kogu kooli loodusteaduste relevantsust õppijate jaoks, mille saavutamisel on kontekstipõhisel õpetamisel oluline koht.

\section{Metoodika}

\section{Valim ja andmete kogumine}

Uurimisküsimustele vastuste saamiseks koguti andmed suuremahulise uuringu „Nutikad tehnoloogiad ja digitaalne kirjaoskus õppimiskäsituse muutmisel" esimese etapi raames 2016. aasta kevadel, kasutades uuringu tarbeks koostatud kompleksinstrumendi neid osi, mis olid seotud huviga eri kontekstide vastu ning motivatsiooniga õppida loodusteaduslikke õppeaineid.

Valimi moodustamiseks valiti Eesti hariduse infosüsteemist (EHIS) välja eesti õppekeelega üldhariduskoolid (tavakoolid), kus 2014/2015. õppeaasta seisuga oli 9. klassides rohkem kui viis õpilast. Andmete kogumiseks 9. klassidest kaasati uuringusse 50 kooli, kuid vastused saadi 46 koolist. Küsimustikule vastasid kõik sel päeval koolis olnud 9. klasside õpilased. Andmete analüüsimiseks kasutati vaid nende õpilaste andmeid, kelle vanem oli nõustunud oma lapse osalemisega uuringus. Seega moodustus lõplik valim 848 õpilasest, kellest 446 olid tüdrukud ja 402 poisid. Õpilased täitsid küsimustiku elektrooniliselt kas kooli arvutiklassis või tahvelarvutite abil tavaklassis. 


\section{Instrument}

Õpilaste huvide andmeid koguti originaalinstrumendiga ning õpimotivatsiooni andmeid modifitseeritud Deci ja Ryani (2015) instrumendiga (tabel 1). Iga loodusteadusliku õppeaine (bioloogia, (loodus)geograafia, keemia, füüsika) kohta esitati 9 väidet (kokku 36 väidet), mis hõlmasid kolme konteksti: ainealast (ainekavast võetud sõnastus) ja teadusliku rakendamise konteksti ning sotsiaal-teaduslikku probleemi kui konteksti. Eri kontekstides esitatud väiteid käsitletakse edaspidi ainesisu (ainekava teemavaldkonda) kajastavate teemadena. Väiteid hindasid õpilased neljapallisel Likerti skaalal järgmiselt: 1 - ei ole nõus, 2 - pigem ei nõustu, 3 pigem nõustun, 4 - nõustun.

Tabel 1. Instrumendi struktuur

\begin{tabular}{|c|c|}
\hline Instrumendi osa & Sisu (teemade arv) \\
\hline $\begin{array}{l}\text { I. Huvi eri } \\
\text { kontekstides } \\
\text { esitatud } \\
\text { loodusteaduslike } \\
\text { teemade } \\
\text { õppimise vastu }\end{array}$ & $\begin{array}{l}36 \text { teemat, mis käsitlesid eri kontekstides õppekavaga seotud } \\
\text { loodusteaduslikku sisu ja kuulusid järgmistesse ainekavade } \\
\text { teemavaldkondadesse: } \\
\text { - bioloogia - taimed (9) } \\
\text { - füüsika - valgusõpetus (3), elektriõpetus (3), mehaanika (3) } \\
\text { - (loodus)geograafia - Maa siseehitus (3), pinnamood (6) } \\
\text { - keemia - aatomiehitus (3), orgaanilised ühendid (3), } \\
\text { anorgaanilised ühendid (3) }\end{array}$ \\
\hline $\begin{array}{l}\text { Il. Õpimotivatsioon } \\
\text { (Deci ja Ryani } \\
\text { (2015) originaal- } \\
\text { instrumendi } \\
\text { põhjal) }\end{array}$ & $\begin{array}{l}20 \text { väidet loodusainete tundide kohta: } \\
\text { - } \text { meeldivus, huvi (4) } \\
\text { - } \text { enesetõhusus (4) } \\
\text { - } \text { tajutud autonoomia (4) } \\
\text { - pingutus (3) } \\
\text { - väärtustamine (5) }\end{array}$ \\
\hline
\end{tabular}

Kõikide teemade ja teemavaldkondade (nt taimed, valgusõpetus, aatomiehitus) valimisel lähtuti põhikooli riiklikust õppekavast (2011), lisaks järgiti teemade õpetamiseks planeeritud aega (nt bioloogias on taimede teema üks mahukaimaid ja seetõttu teisi teemavaldkondi ei lisatud). Kontekstide loomisel tugineti autorite varasemate uuringute tulemustele ja kontekstitüüpide määratlusele kirjanduses (De Jong, 2006; Gilbert, 2006; Teppo \& Rannikmäe, 2008). Konkreetsed näited taimede teemavaldkonna teemade esitamise kontekstide kohta on toodud tabelis 2 . 
Tabel 2. Näide taimede teemaga seotud kontekstide kohta

\begin{tabular}{|c|c|c|c|}
\hline \multirow{2}{*}{$\begin{array}{l}\text { Relevantsuse } \\
\text { kategooriad }\end{array}$} & \multicolumn{3}{|c|}{ Kontekstide kategooriad } \\
\hline & $\begin{array}{l}\text { Ainekava kui } \\
\text { kontekst }\end{array}$ & $\begin{array}{c}\text { Teadusliku rakendami- } \\
\text { se kontekst }\end{array}$ & $\begin{array}{c}\text { Sotsiaal-teaduslik } \\
\text { probleem kui kontekst }\end{array}$ \\
\hline $\begin{array}{l}\text { Õppekava } \\
\text { relevantsus }\end{array}$ & $\begin{array}{l}\text { Eri taimerühmadele } \\
\text { iseloomulik välisehitus, } \\
\text { paljunemisviis, } \\
\text { kasvukoht ja levik }\end{array}$ & $\begin{array}{l}\text { Õistaimede organite } \\
\text { ehituse sõltuvus } \\
\text { nende ülesannetest }\end{array}$ & $\begin{array}{l}\text { Fotosünteesiks kõige } \\
\text { soodsamate tingimuste } \\
\text { loomine kasvuhoones, } \\
\text { et suurendada saagist } \\
\text { saadavat tulu }\end{array}$ \\
\hline $\begin{array}{l}\text { Sotsiaalne } \\
\text { relevantsus }\end{array}$ & $\begin{array}{l}\text { Minu kodukohas } \\
\text { kasvavate taimede } \\
\text { paljunemise ja } \\
\text { levimise viisid }\end{array}$ & $\begin{array}{l}\text { Taimede tähtsus } \\
\text { looduse kui tervik- } \\
\text { süsteemi jätku- } \\
\text { suutlikkuse tagamisel } \\
\text { ja inimtegevuses }\end{array}$ & $\begin{array}{l}\text { Teave selle kohta, } \\
\text { millised teadmised } \\
\text { taimedest on eri elu- } \\
\text { kutsetega inimestele } \\
\text { vajalikud, et nad olek- } \\
\text { sid oma töös edukad }\end{array}$ \\
\hline $\begin{array}{l}\text { Personaalne } \\
\text { relevantsus }\end{array}$ & $\begin{array}{l}\text { Mürktaimed ja } \\
\text { neile iseloomulikud } \\
\text { tunnused }\end{array}$ & $\begin{array}{l}\text { Mürktaimede } \\
\text { toimeained ja nende } \\
\text { mõju organismile }\end{array}$ & $\begin{array}{l}\text { Mürktaimede raviva } \\
\text { ja surmava doosi } \\
\text { eristamine }\end{array}$ \\
\hline
\end{tabular}

Adapteerimise tulemusena kasutati järgmisi Deci ja Ryani (2015) väljatöötatud sisemise motivatsiooni mõõtmise instrumendi osi: huvi, enesetõhusus, tajutud autonoomia, pingutus ning väärtustamine (tabel 1). Õpilased hindasid väiteid viiepallisel Likerti skaalal järgmiselt: 1 - ei nõustu, 2 - pigem ei nõustu, 3 - nii ja naa, 4 - pigem nõustun, 5 - nõustun. Kuivõrd Eesti õppekavas on neli eraldiseisvat loodusteaduslikku õppeainet, siis ühe ja sama klassi õpilased lähtusid selles küsimustiku osas eri õppeainetest.

Mõlemat instrumendi osa kontrolliti esmalt 9. klassi õpilaste peal, seejärel tehti vajalikud sõnastusparandused. Huvide osa valideeriti ka eksperdimeetodil. Valideerimise käigus kategoriseerisid neli loodusainete õpetajat ja kaks rahvusvahelist eksperti teemasid konteksti kategooria kirjelduse järgi. Kategooriate kokkulangevus oli 92\%. Originaalinstrumendi eksperdivalideerimine korraldati kahes etapis, kuna esmase valideerimise tulemusena tuli muuta mitme väite sõnastust.

\section{Andmeanalüïs}

Andmete statistiline analüüs tehti statistikaprogrammiga SPSS 23.0. Kirjeldavad statistikud (keskmine, standardhälve) leiti nii üksikväidete (tabelid 5 ja 6) kui ka peakomponentide (tabelid 4 ja 7) kohta. Sooliste erinevuste väljaselgitamiseks kasutati sõltumatute valimite t-testi, kuivõrd kogutud andmed vastavad normaaljaotusele. Instrumendi usaldusväärsuse hindamiseks arvutati Cronbachi a väärtused küsimustiku mõlema osa 
kohta: huvi osas $\alpha=0,97$ ja suhtumise osas $\alpha=0,88$, mis näitasid tugevat sisemist (> 0,70) kooskõla (Hair, William, Babin, \& Anderson, 2010). Õpilaste vastuste kirjeldamiseks ja tunnuste grupeerimiseks nii huvide kui ka motivatsiooni osas rakendati peakomponentide (principal component) analüüsi koos varimaks-pööramisega (varimax rotation). Peakomponentide analüüsis kasutati ka kaldpööramise (oblimini ja promaksi) meetodeid, mille korral olid tulemused (nii kumulatiivne kirjeldatuse protsent kui ka peakomponentide sisuline kattuvus) samasugused, mistõttu otsustati jääda varimaks-pööramise juurde. Lisaks on see kõige levinum ja enim kasutatav pööramismeetod (Osborne, 2015). Kirjanduse järgi peetakse heaks faktoranalüüsi mudelit, mis kirjeldab minimaalselt 70\% algtunnuste variatiivsusest (Stevens, 2009), samas Merenda (1997) arvates võib see olla 50\%.

K-keskmiste klasteranalüüsi kasutati õpilaste grupeerimiseks (õpilaste motivatsiooniprofiilide väljaselgitamiseks) nende omavahelise sarnasuse alusel, lähtudes sellest, missugune on nende motivatsioon õppida loodusaineid (bioloogiat, geograafiat, keemiat või füüsikat). K-keskmiste klasteranalüüsi otsustati kasutada seetõttu, et objekte (õpilasi) oli palju ning eeldati, et õpilased võiksid jaguneda kolme gruppi, võttes arvesse kontrolluuringu tulemusi. Klasteranalüüs tehti ka kahe ja nelja klastriga ning tulemused näitasid, et klastrite tsentrid olid kolmeklastrilise lahendi puhul üksteisest võimalikult kaugel, mistõttu otsustati jääda sellise lahendi juurde.

\section{Tulemused}

\section{Õpilaste huvi eri kontekstides esitatud loodusteaduslike teemade õppimise vastu}

Uurimistulemused näitavad, et õpilaste huvi sõltub nii kontekstist kui ka loodusteaduslikust õppeainest. Tulemuste väljaselgitamiseks tehti peakomponentide analüüs, mis võimaldas eristada viit peakomponenti (edaspidi: huvi dimensioonid ehk H-dimensioonid), mis kirjeldavad õpilaste huve teemade kontekstuaalsuse ja konkreetse õppeaine aspektist kokku 66,1\% ulatuses (tabel 3). KMO (Kaiser-Meyer-Olkin) näitaja $(0,97)$ ja Bartletti test $\left(\chi^{2}=22\right.$ 972,0; $\left.d f=630 ; p<0,001\right)$ kinnitasid peakomponentide analüüsi kasutamise olulisust. Peakomponentide sisereliaablus oli suur, jäädes vahemikku 0,86-0,92.

$\mathrm{H}$-dimensioonid eristuvad nii õppeaineti (pinnamood, taimed) kui ka konteksti alusel. Üksnes teadusliku ainesisu (st ainekava sisus loetletud pealkirjade) põhjal moodustus $\mathrm{H}$-dimensioon aatomiehituse ja vooluringiga seotud abstraktsetest teemadest, mis on füüsika- ja keemiaspetsiifilised. 
Eraldi bioloogia kui õppeaine spetsiifilise H-dimensiooni moodustasid kõik üheksa taimedega seotud teemat. Sarnane H-dimensioon eristus ka geograafiaspetsiifilisena pinnamoetemaatikaga seotud väidete põhjal. Personaalsete ja sotsiaalsete kontekstide interdistsiplinaarset iseloomu kirjeldavad kaks õppeaineteülest H-dimensiooni - tehnoloogilised rakendused ja loodusnähtused -, milles sisalduvad vastavalt füüsika- ja keemiaspetsiifilised ning füüsika- ja geograafiaspetsiifilised teemad.

Tabel 3. Huvide kontekstuaalsust kirjeldavad dimensioonid

\begin{tabular}{l|l|c|c|c}
\hline $\begin{array}{l}\text { H-dimensioon } \\
\text { (õppeaine) }\end{array}$ & Kirjeldus & $\begin{array}{c}\text { Teemade } \\
\text { arv }\end{array}$ & $\begin{array}{c}\text { Kumulatiivne } \\
\text { kirjeldatuse \% }\end{array}$ & $\begin{array}{c}\text { Cronbachi } \\
a\end{array}$ \\
\hline $\begin{array}{l}\text { 1. Tehnoloogilised } \\
\text { rakendused } \\
\text { (füüsika + keemia) }\end{array}$ & $\begin{array}{l}\text { Elektrivoolu, optika ja } \\
\text { orgaaniliste ainetega } \\
\text { seotud teemad, mis on } \\
\text { esitatud personaalses ja } \\
\text { sotsiaalses kontekstis }\end{array}$ & 10 & 15,7 & 0,92 \\
\hline $\begin{array}{l}\text { 2. Pinnamood } \\
\text { (loodusgeograafia) }\end{array}$ & $\begin{array}{l}\text { Pinnamoega seotud } \\
\text { teemad eri kontekstides }\end{array}$ & 6 & 30,4 & 0,93 \\
\hline $\begin{array}{l}\text { 3. Taimed } \\
\text { (bioloogia) }\end{array}$ & $\begin{array}{l}\text { Taimedega seotud teemad } \\
\text { eri kontekstides }\end{array}$ & 9 & 42,7 & 0,91 \\
\hline $\begin{array}{l}\text { 4. Abstraktsed } \\
\text { teemad } \\
\text { (füüsika + keemia) }\end{array}$ & $\begin{array}{l}\text { Aatomiehituse ja voolu- } \\
\text { ringiga seotud ainealased } \\
\text { teemad }\end{array}$ & 5 & 54,5 & 0,89 \\
\hline $\begin{array}{l}\text { 5. Loodusnähtused } \\
\text { (füüsika + } \\
\text { loodusgeograafia) }\end{array}$ & $\begin{array}{l}\text { Erinevad loodusnähtused } \\
\text { esitatuna personaalses ja } \\
\text { sotsiaalses kontekstis }\end{array}$ & 6 & 66,1 & 0,86 \\
\hline
\end{tabular}

Huvi dimensioone võrreldi poiste ja tüdrukute puhul eraldi. Tabelist 4 selgub, et taimede $(M=2,56 ; p<0,005)$ ja erinevate loodusnähtustega $(M=2,76 ; p<0,005)$ seotud temaatika pakub statistiliselt olulisel määral enam huvi tüdrukutele kui poistele. Aatomiehituse ja vooluringiga seotud teemad neljandas $\mathrm{H}$-dimensioonis on aga statistiliselt olulisel määral rohkem huvipakkuvad poistele $(M=2,35 ; p<0,005)$ kui tüdrukutele. Samas on huvi viimati nimetatud teemade õppimise vastu siiski tagasihoidlik, seda eriti tüdrukute puhul. Õpilastele (nii poistele kui ka tüdrukutele) kõige huvipakkuvamad teemad koondusid viimasesse, erinevate loodusnähtustega seotud H-dimensiooni. Õpilaste huvide varieeruvus nende $\mathrm{H}$-dimensioonide sees jääb nii poistel kui ka tüdrukutel ühtlaselt vahemikku $S D=0,70-0,81$, mis viitab õpilaste huvide erinevustele. 
Tabel 4. Poiste ja tüdrukute huvide erinevused H-dimensioonide kaupa

\begin{tabular}{l|c|c|c|c|c|c|c|c|c}
\hline \multirow{2}{*}{ H-dimensioon } & \multicolumn{2}{|c|}{$\begin{array}{c}\text { Tüdrukud } \\
(N=446)\end{array}$} & \multicolumn{2}{c|}{$\begin{array}{c}\text { Poisid } \\
(N=402)\end{array}$} & \multicolumn{2}{|c|}{$\begin{array}{c}\text { Kokku } \\
(N=848)\end{array}$} & $d f$ & $t$ & $p$ \\
\cline { 2 - 7 } & $M$ & $S D$ & $M$ & $S D$ & $M$ & $S D$ & & & \\
\hline $\begin{array}{l}\text { 1. Tehnoloogilised } \\
\text { rakendused }\end{array}$ & 2,29 & 0,74 & 2,31 & 0,74 & 2,30 & 0,74 & 847 & 0,27 & 0,789 \\
\hline 2. Pinnamood & 2,27 & 0,78 & 2,35 & 0,78 & 2,32 & 0,75 & 847 & 1,60 & 0,110 \\
\hline $\begin{array}{l}\text { 3. Taimed } \\
\text { 4. Abstraktsed } \\
\text { teemad }\end{array}$ & 2,56 & 0,76 & 2,38 & 0,76 & 2,47 & 0,77 & 847 & $-3,34$ & $<0,005$ \\
\hline $\begin{array}{l}\text { 5. Loodus- } \\
\text { nähtused }\end{array}$ & 2,76 & 0,70 & 2,54 & 0,73 & 2,66 & 0,72 & 847 & $-4,61$ & $<0,005$ \\
\hline
\end{tabular}

Märkused. $M$ - aritmeetiline keskmine; $S D$ - standardhälve; $N$ - õpilaste arv; $d f$ - vabadusastmete arv.

Analüüsides õpilaste huvi kõigi 36 teema õppimise vastu järjestatuna üldkeskmiste väärtuste alusel, selgub, et kõige huvipakkuvamad teemad on õpilaste jaoks looduskatastroofid ja mürktaimed, kui need on esitatud sotsiaal-teadusliku probleemi või teadusliku rakendamise kontekstis (tabel 5). Peaaegu kõik viiendasse H-dimensiooni kuuluvad teemad (5 teemat 6st) on esindatud ka kümne kõige huvipakkuvama teema seas (üldkeskmine väärtus suurem kui 2,5) ja seda nii poiste kui ka tüdrukute arvates. Kümme kõige vähem huvipakkuvat teemat (keskmine väärtus väiksem kui 2,3) seostusid aatomiehituse, orgaaniliste ainete keemiliste omaduste ja pinnavormide temaatikaga just ainealases kontekstis. Seega rõhutab eelöeldu üksikute loodusteaduslike õppeainete spetsiifikaga seotud suundumusi õpilaste vastustes. 
Tabel 5. Õpilastele kõige enam ja kõige vähem huvipakkuvad teemad järjestatuna üldkeskmiste väärtuste alusel

\begin{tabular}{|c|c|c|c|c|c|c|}
\hline \multirow[t]{2}{*}{ Teema (H-dimensiooni number tabelis 4) } & \multicolumn{2}{|c|}{$\begin{array}{l}\text { Poisid } \\
(N=402)\end{array}$} & \multicolumn{2}{|c|}{$\begin{array}{l}\text { Tüdrukud } \\
(N=446)\end{array}$} & \multicolumn{2}{|c|}{$\begin{array}{c}\text { Kokku } \\
(N=848)\end{array}$} \\
\hline & $M$ & $S D$ & $M$ & $S D$ & $M$ & $S D$ \\
\hline $\begin{array}{l}\text { Mind huvitavad looduskatastroofid - } \\
\text { maavärinad, üleujutused, tormid (H-D5) }\end{array}$ & 2,79 & 0,92 & 3,07 & 0,88 & $2,94^{*}$ & 0,91 \\
\hline $\begin{array}{l}\text { Tahan rohkem teada saada mürktaimedest, } \\
\text { et eristada ravivat ja surmavat kogust } \\
\text { (H-D3) }\end{array}$ & 2,68 & 0,95 & 2,93 & 0,94 & $2,81^{*}$ & 0,95 \\
\hline $\begin{array}{l}\text { Mind huvitab, missugune on taimede } \\
\text { tähtsus looduses ja inimeste elus (H-D3) }\end{array}$ & 2,56 & 0,94 & 2,85 & 0,92 & $2,71^{*}$ & 0,94 \\
\hline $\begin{array}{l}\text { Mind huvitab, kuidas kliima mõjutab } \\
\text { looduskatastroofide tekkimist (H-D5) }\end{array}$ & 2,63 & 0,94 & 2,77 & 0,97 & $2,70^{*}$ & 0,96 \\
\hline $\begin{array}{l}\text { Tahan rohkem teada saada optilistest } \\
\text { nähtustest taevas (H-D5) }\end{array}$ & 2,56 & 0,95 & 2,73 & 1,00 & $2,65^{*}$ & 0,98 \\
\hline $\begin{array}{l}\text { Tahan rohkem teada saada mürktaimedest } \\
\text { ja nende mõjust organismile (H-D3) }\end{array}$ & 2,51 & 1,02 & 2,76 & 0,96 & $2,64^{*}$ & 0,99 \\
\hline $\begin{array}{l}\text { Mind huvitavad liiklusõnnetuste põhjused } \\
\text { ning nende tekitatud kahju ühiskonnale } \\
\text { (H-D5) }\end{array}$ & 2,48 & 0,96 & 2,74 & 0,91 & $2,62^{*}$ & 0,94 \\
\hline $\begin{array}{l}\text { Tahan rohkem teada saada mürktaimedest } \\
\text { ja nende iseloomulikest tunnustest (H-D3) }\end{array}$ & 2,49 & 0,98 & 2,72 & 0,98 & $2,61^{*}$ & 0,98 \\
\hline $\begin{array}{l}\text { Mind huvitab, kuidas erinevad loodus- } \\
\text { katastroofid mõjutavad turismi arengut } \\
\text { (H-D5) }\end{array}$ & 2,52 & 0,95 & 2,69 & 0,97 & $2,61^{*}$ & 0,97 \\
\hline $\begin{array}{l}\text { Tahan rohkem teada saada oma kodukoha } \\
\text { looduslikest vaatamisväärsustest (H-D2) }\end{array}$ & 2,43 & 0,98 & 2,52 & 0,96 & 2,48 & 0,97 \\
\hline \multicolumn{7}{|l|}{$\cdots$} \\
\hline $\begin{array}{l}\text { Mulle meeldib õppida, kuidas erinevate } \\
\text { pinnavormide kujunemise protsess } \\
\text { mõjutab neile iseloomulikke tunnuseid } \\
\text { (H-D2) }\end{array}$ & 2,30 & 0,93 & 2,22 & 0,96 & 2,26 & 0,95 \\
\hline $\begin{array}{l}\text { Mind huvitavad minu kodukohas kasvavate } \\
\text { taimede paljunemise ja levimise viisid } \\
\text { (H-D3) }\end{array}$ & 2,18 & 0,97 & 2,29 & 1,00 & 2,24 & 0,99 \\
\hline $\begin{array}{l}\text { Ma tahan õppida aatomite ja molekulide } \\
\text { kui aine väikseimate osakeste kohta (H-D4) }\end{array}$ & 2,32 & 0,98 & 2,16 & 1,01 & $2,23^{*}$ & 0,99 \\
\hline
\end{tabular}




\begin{tabular}{l|c|c|c|c|c|c}
\hline Teema (H-dimensiooni number tabelis 4) & \multicolumn{2}{|c|}{$\begin{array}{c}\text { Poisid } \\
(N=402)\end{array}$} & \multicolumn{2}{c|}{$\begin{array}{c}\text { Tüdrukud } \\
(N=446)\end{array}$} & \multicolumn{2}{|c}{$\begin{array}{c}\text { Kokku } \\
(N=848)\end{array}$} \\
\cline { 2 - 7 } & $M$ & $S D$ & $M$ & $S D$ & $M$ & $S D$ \\
\hline $\begin{array}{l}\text { Mulle meeldib õppida, kuidas õistaimede } \\
\text { organite ehitus sõltub nende ülesannetest } \\
\text { (H-D3) }\end{array}$ & 2,23 & 0,96 & 2,24 & 0,97 & 2,23 & 0,96 \\
\hline $\begin{array}{l}\text { Tahan rohkem teada saada pesemisvahendi } \\
\text { koostise ja selle tõhususe seosest pesu } \\
\text { pesemisel (H-D1) }\end{array}$ & 2,18 & 0,93 & 2,27 & 0,98 & 2,23 & 0,96 \\
\hline $\begin{array}{l}\text { Mulle meeldib teada saada, kuidas } \\
\text { kodumasinate energiamärgistus mõjutab } \\
\text { elektrivoolu tarbimist (H-D1) }\end{array}$ & 2,34 & 0,94 & 2,12 & 0,92 & $2,23^{*}$ & 0,94 \\
\hline $\begin{array}{l}\text { Mulle meeldib õppida, kuidas pinnamood } \\
\text { mõjutab põllumajandusest saadavat tulu } \\
\text { (H-D2) }\end{array}$ & 2,26 & 0,94 & 2,12 & 0,91 & $2,19^{*}$ & 0,92 \\
\hline $\begin{array}{l}\text { Mulle meeldib õppida metallide aatomi } \\
\text { ehituse mõju nende keemilistele ja } \\
\text { füüsikalistele omadustele (H-D4) }\end{array}$ & 2,33 & 0,95 & 2,04 & 0,97 & $2,18^{*}$ & 0,97 \\
\hline $\begin{array}{l}\text { Ma tahan õppida mandrijää poolt } \\
\text { kujundatud pinnavorme (H-D2) }\end{array}$ & 2,20 & 0,95 & 2,11 & 0,90 & 2,15 & 0,92 \\
\hline $\begin{array}{l}\text { Tahan rohkem teada saada pesemis- } \\
\text { vahendite keemilistest omadustest (H-D1) }\end{array}$ & 2,15 & 0,93 & 2,15 & 0,95 & 2,15 & 0,94 \\
\hline
\end{tabular}

Märkused. $M$ - aritmeetiline keskmine; SD - standardhälve; $N$ - õpilaste arv; $D$ - peakomponent ehk dimensioon, kuhu väide kuulub; ${ }^{*}$ - statistiliselt oluline erinevus poiste ja tüdrukute vahel usaldusnivool 0,05.

\section{Õpilaste õpimotivatsioon}

Õpilased ei vastanud motivatsiooni osa küsimustele mitte kõigi nelja loodusaine kohta, vaid ainult ühe loodusaine (bioloogia, geograafia, keemia või füüsika) piires. See, millise konkreetse õppeaine õpimotivatsiooni õpilane hindas, toimus juhuslikkuse alusel. Samamoodi nagu huvide väljaselgitamiseks, kasutati ka õpimotivatsiooni kirjeldamiseks ja väidete grupeerimiseks peakomponentide analüüsi, mille tarbeks lisati analüüsi peale 20 väite ka konkreetset õppeainet eristav nominaaltunnus. Analüüsi tulemusel eristus viis peakomponenti (motivatsiooni dimensiooni) kogukirjeldatusega 73\% (tabel 6). KMO (Kaiser-Meyer-Olkin) näitaja $(0,94)$ ja Bartletti test $\left(\chi^{2}=13454,0 ; d f=210 ; p<0,005\right)$ kinnitasid peakomponentide analüüsi kasutamise olulisust. Õpilaste õpimotivatsiooni kõige enam kirjeldav (46\%) ja suure sisemise koherentsusega $(\alpha=0,93)$ M-dimensioon seostub meeldivuse, huvi ja rahuloluga ning seega võib seda nimetada 
sisemise motivatsiooni M-dimensiooniks. See mõõdab õpilaste hinnanguid loodusainete õppimise kohta nii otseste indikaatorite (huvi) kui ka kaudsete indikaatorite (autonoomia, enesetõhususe) kaudu. Teine dimensioon kirjeldab seda, kuivõrd õpilased väärtustavad loodusainete õppimist koolis ja väljaspool kooli. Kolmandat M-dimensiooni saab nimetada pingutuseks ehk see kirjeldab õpilaste püüdlusi loodusainetest aru saada ja loodusaineid hästi õppida. Neljas M-dimensioon kirjeldab õpilaste negatiivset hoiakut (igav või kohustuslik õppida) loodusteaduslike õppeainete õppimise suhtes. Viies ehk valimit kõige vähem (4\%) kirjeldav M-dimensioon - loodusaine - eristus eraldiseisva peakomponendina, korreleerumata teiste väidetega, ning seetõttu pole selle dimensiooni mõju valimi kirjeldamisel määrav ning see annab aluse käsitleda peakomponentide analüüsi tulemusi loodusaineteüleselt.

Tabel 6. Õpilaste õpimotivatsiooni kirjeldavad dimensioonid

\begin{tabular}{|c|c|c|c|c|c|c|c|}
\hline \multirow{2}{*}{$\begin{array}{l}\text { M-dimensioonide nimetused ja } \\
\text { väited }\end{array}$} & \multirow[b]{2}{*}{$M$} & \multirow[b]{2}{*}{$S D$} & \multicolumn{5}{|c|}{ Peakomponendid } \\
\hline & & & 1 & 2 & 3 & 4 & 5 \\
\hline \multicolumn{8}{|l|}{ 1. Sisemine motivatsioon } \\
\hline $\begin{array}{l}\text { Ma oskan päris hästi (ainet*) } \\
\text { õppida }\end{array}$ & 3,50 & 1,07 & 0,88 & & & & \\
\hline $\begin{array}{l}\text { Saan (aine) tundides õpitust päris } \\
\text { hästi aru }\end{array}$ & 3,57 & 1,07 & 0,87 & & & & \\
\hline $\begin{array}{l}\text { Ma olen rahul sellega, kuidas ma } \\
\text { saan (aine) tundides õppimisega } \\
\text { hakkama }\end{array}$ & 3,59 & 1,09 & 0,85 & & & & \\
\hline $\begin{array}{l}\text { Saan (aine) tundides päris hästi } \\
\text { hakkama }\end{array}$ & 3,63 & 1,04 & 0,84 & & & & \\
\hline Mulle meeldib väga (ainet) õppida & 3,23 & 1,13 & 0,68 & & & & \\
\hline (Ainet) on tore õppida & 3,26 & 1,14 & 0,68 & & & & \\
\hline (Ainet) on väga huvitav õppida & 3,22 & 1,16 & 0,62 & & & & \\
\hline $\begin{array}{l}\text { (Aine) tundides on mul võimalus } \\
\text { valida, kuidas ma õpin }\end{array}$ & 3,04 & 1,12 & 0,60 & & & & \\
\hline Ma õpin (ainet), sest ma tahan seda & 3,14 & 1,15 & 0,58 & & & & \\
\hline \multicolumn{8}{|l|}{ 2. Loodusainete väärtustamine } \\
\hline $\begin{array}{l}\text { (Aine) tundides õpitu võib olla } \\
\text { mulle kasulik erinevate } \\
\text { probleemide lahendamisel }\end{array}$ & 3,55 & 1,03 & & 0,79 & & & \\
\hline
\end{tabular}




\begin{tabular}{|c|c|c|c|c|c|c|c|}
\hline \multirow{2}{*}{$\begin{array}{l}\text { M-dimensioonide nimetused ja } \\
\text { väited }\end{array}$} & \multirow[b]{2}{*}{$M$} & \multirow[b]{2}{*}{$S D$} & \multicolumn{5}{|c|}{ Peakomponendid } \\
\hline & & & 1 & 2 & 3 & 4 & 5 \\
\hline $\begin{array}{l}\text { Ma saan (aine) tundides õpitut } \\
\text { kasutada ka väljaspool kooli }\end{array}$ & 3,51 & 1,12 & & 0,74 & & & \\
\hline $\begin{array}{l}\text { (Aine) tundides toimuv õppetöö on } \\
\text { mulle kasulik }\end{array}$ & 3,62 & 1,03 & & 0,73 & & & \\
\hline $\begin{array}{l}\text { (Aine) tunnid on mulle kasulikud, } \\
\text { kuna ma omandan juurde palju } \\
\text { uusi teadmisi ja oskusi }\end{array}$ & 3,64 & 1,04 & & 0,73 & & & \\
\hline $\begin{array}{l}\text { (Aine) tunnis õpime asju, mida elus } \\
\text { vaja ei lähe }(-)\end{array}$ & 2,66 & 1,08 & & $-0,61$ & & & \\
\hline \multicolumn{8}{|l|}{ 3. Pingutus } \\
\hline $\begin{array}{l}\text { Ma pingutan palju, et (ainest) aru } \\
\text { saada }\end{array}$ & 3,01 & 1,08 & & & 0,85 & & \\
\hline $\begin{array}{l}\text { Ma valmistun põhjalikult (aines) } \\
\text { tehtavateks töödeks }\end{array}$ & 3,22 & 1,12 & & & 0,78 & & \\
\hline $\begin{array}{l}\text { Minu jaoks on oluline (ainet) hästi } \\
\text { õppida }\end{array}$ & 3,43 & 1,12 & & & 0,59 & & \\
\hline \multicolumn{8}{|l|}{ 4. Negatiivne hoiak } \\
\hline $\begin{array}{l}\text { Ma õpin (ainet), sest mul ei ole teist } \\
\text { valikut (-) }\end{array}$ & 2,97 & 1,20 & & & & 0,77 & \\
\hline (Ainet) on igav õppida (-) & 2,67 & 1,17 & & & & 0,67 & \\
\hline Ma pean (ainet) õppima (-) & 3,46 & 1,06 & & & & 0,55 & \\
\hline 5. Loodusaine* & & & & & & & 0,96 \\
\hline Kumulatiivse kirjeldatuse \% & & & 45,6 & 55,5 & 63,3 & 69,2 & 73,3 \\
\hline Cronbachi a & & & 0,93 & 0,68 & 0,76 & 0,54 & \\
\hline
\end{tabular}

Märkused. $M$ - aritmeetiline keskmine; SD - standardhälve; * aine - bioloogia, geograafia, keemia, füüsika; (-) väited on ümberpööramata kujul.

Keskmised väärtused väidete kohta tabelis 6 näitavad, et õpilaste hinnangud loodusteaduste tundidele on valdavalt positiivsed: nad on rahul loodusainete õppimisega koolis ning väärtustavad loodusainetes õpitavat väljaspool kooli (igapäevaelus). Kõige enam on õpilased nõus sellega, et loodusainete tunnid on neile kasulikud, kuna nad omandavad tundides palju uusi teadmisi ja oskusi $(M=3,64)$, ning et nad saavad loodusainete tundides hästi hakkama $(M=3,63)$. 
Kui võrrelda poiste ja tüdrukute erinevusi õpimotivatsiooni kirjeldavate M-dimensioonide alusel, siis ilmneb, et statistiliselt olulised erinevused poiste ja tüdrukute vahel seisnevad kahes M-dimensioonis: loodusainete väärtustamises ja pingutuses (tabel 7). Loodusainete õppimist väärtustavad ning õppides pingutavad tüdrukud statistiliselt olulisel määral enam kui poisid. Sisemise motivatsiooni ja negatiivse hoiaku M-dimensioonide puhul soolisi erinevusi ei esine, küll aga selgub andmete analüüsist, et poiste üldkeskmine hinnang oma soovile loodusaineid õppida on veidi kõrgem kui tüdrukutel. Tabeli 7 põhjal võib väita, et kõige enam on õpilased ühel meelel loodusainete väärtustamises - selle dimensiooni standardhälve on nii poistel kui ka tüdrukutel 0,70. Kõige suuremad erinevused õpilaste hinnangutes esinevad sisemise motivatsiooni ja pingutuse M-dimensioonides.

Tabel 7. Poiste ja tüdrukute hinnangute erinevused õpimotivatsiooni kirjeldavate M-dimensioonide puhul

\begin{tabular}{l|c|c|c|c|c|c|c|c|c}
\hline M-dimensioonid & \multicolumn{2}{|c|}{$\begin{array}{c}\text { Tüdrukud } \\
(N=446)\end{array}$} & \multicolumn{2}{c|}{$\begin{array}{c}\text { Poisid } \\
(N=402)\end{array}$} & \multicolumn{2}{c|}{$\begin{array}{c}\text { Kokku } \\
(N=848)\end{array}$} & & & \\
\cline { 2 - 11 } & $M$ & $S D$ & $M$ & $S D$ & $M$ & $S D$ & $d f$ & $t$ & $p$ \\
\hline $\begin{array}{l}\text { 1. Sisemine moti- } \\
\text { vatsioon }\end{array}$ & 3,34 & 0,94 & 3,37 & 0,88 & 3,36 & 0,91 & 847 & 0,39 & 0,70 \\
\hline $\begin{array}{l}\text { 2. Loodusainete } \\
\text { väärtustamine }\end{array}$ & 3,44 & 0,70 & 3,34 & 0,70 & 3,40 & 0,70 & 847 & $-2,04$ & 0,04 \\
\hline 3. Pingutus & 3,35 & 0,92 & 3,09 & 0,88 & 3,22 & 0,91 & 847 & $-4,24$ & $<0,05$ \\
\hline 4. Negatiivne hoiak & 3,04 & 0,86 & 3,03 & 0,80 & 3,04 & 0,83 & 847 & $-0,10$ & 0,92 \\
\hline
\end{tabular}

Märkused. $M$ - aritmeetiline keskmine; SD - standardhälve; $d f$ - vabadusastmete arv.

\section{Õpilasi kirjeldavad profiilid õppeaineti}

Uurimistöös kasutati õpilaste profiilide loomiseks k-keskmiste klasteralüüsi ning aluseks võeti instrumendi õpimotivatsiooni osa ja selle põhjal leitud neli esimest dimensiooni (sisemine motivatsioon, väärtustamine, pingutus ja negatiivne hoiak). Kuivõrd õpilased vastasid motivatsiooni osa väidetele ühe loodusteadusliku õppeaine (bioloogia, geograafia, keemia või füüsika) spetsiifiliselt, siis tehti klasteranalüüs samuti neljal korral ehk iga õppeaine puhul eraldi, kuid huvi ja motivatsiooniga seonduvat võrreldi klastrite kaupa tabelites 4 ja 6 välja toodud $\mathrm{H}$ - ja M-dimensioonide kaudu.

Igal klasteranalüüsil eristus kolm klastrit: kõrge, keskmise ja madala motivatsioonimääraga õpilased bioloogias, geograafias, keemias ja füüsikas (tabel 8). Õpilaste jaotumine selle järgi, missuguse loodusteadusliku 
õppeaine motivatsiooni osale üks või teine õpilane vastas, on suhteliselt sarnane, jäädes vahemikku 192 (füüsikas) kuni 216 (geograafias). Samas aga erinevad kolme klastri sees poiste ja tüdrukute arv oluliselt - keemias on kõrge motivatsioonimääraga klastris tüdrukuid poole rohkem kui poisse (vastavalt 50 ja 23), ka madala motivatsioonimääraga klastris bioloogias ja füüsikas on tüdrukuid enam kui poisse. Samuti erinevad õppeainete sees klastritesse kuuluvate õpilaste arvud. Kui keemias, füüsikas ja geograafias on keskmise motivatsioonimääraga klastritesse kuuluvaid õpilasi kõige enam, siis bioloogias on nii madala kui ka keskmise motivatsioonimääraga õpilasi suhteliselt võrdselt (vastavalt 88 ja 85 õpilast). Kõigi 12 klastri võrdluses kuulub kõige vähem õpilasi $(N=17)$ madala motivatsioonimääraga klastrisse geograafias.

Tabel 8 annab ülevaate eri klastritesse kuuluvate õpilaste huvi ja motivatsiooniga seotud suundumustest: punasega on märgitud õpilaste negatiivne suundumus (ei ole huvitatud, ei nõustu), oranžiga keskmine suundumus (üldkeskmine väärtus on huvide puhul vahemikus 2,45-2,55 või motivatsiooni puhul vahemikus 2,95-3,05) ning rohelisega positiivne suundumus (on huvitatud, nõustub). Tulemused näitavad, et klastritevahelised statistiliselt olulised erinevused õppeaine sees nii huvi kui ka motivatsiooni dimensioonide puhul esinevad peaaegu kõikidel juhtudel, v.a keemia keskmise ja kõrge motivatsioonimääraga õpilaste vahel pinnamoe dimensioonis, bioloogia madala ja keskmise motivatsioonimääraga õpilaste vahel abstraktsete teemade dimensioonis ning füüsika madala ja keskmise motivatsioonimääraga õpilaste vahel loodusnähtuste dimensioonis. Motivatsiooni dimensioonide puhul ei esinenud statistiliselt olulisi erinevusi madala ja keskmise motivatsioonimääraga õpilaste vahel üksnes geograafia negatiivse hoiaku dimensioonis.

Tulemused osutavad tendentsile, mille järgi on kõrge sisemise motivatsiooni määraga õpilased bioloogias, keemias ja füüsikas huvitatud kõikide loodusteaduslike teemade õppimisest, sõltumata nende esitamise kontekstist (üldkeskmised on kõikidel juhtudel dimensioonide lõikes suuremad kui 2,59) (tabelid 1-4 lisas 1). Nendel õpilastel on eriline huvi loodusnähtuste õppimise vastu (üldkeskmised väärtused vahemikus 2,86-3,18). Samas kõrge motivatsioonimääraga õpilased geograafia klastris tunnevad suurt huvi vaid pinnamoe, taimede ja loodusnähtuste óppimise vastu, tehnoloogilised rakendused $(M=2,49)$ ja abstraktsed teemad $(M=2,48)$ on nende jaoks vähem huvitavad. Kõrge motivatsioonimääraga klastritesse kuuluvatel õpilastel on suur sisemine motivatsioon õppida loodusaineid, nad pingutavad loodusainete õppimisel palju ning väärtustavad loodusainete õppimist nii koolis kui ka väljaspool kooli. 
Tabel 8. Eri klastritesse kuuluvate õpilaste suundumused huvi ja motivatsiooni kirjeldavate dimensioonide lõikes

\begin{tabular}{|c|c|c|c|c|c|c|c|c|c|}
\hline \multirow{2}{*}{$\begin{array}{l}\text { Õppeained ja } \\
\text { klastrid }\end{array}$} & \multicolumn{5}{|c|}{ H-dimensioonid } & \multicolumn{4}{|c|}{ M-dimensioonid } \\
\hline & 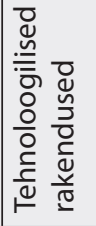 & 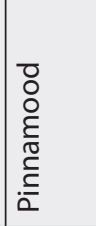 & 离 & 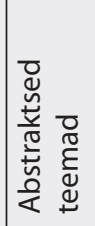 & 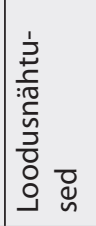 & 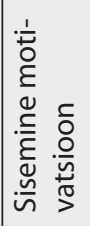 & 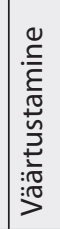 & 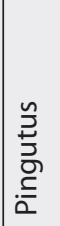 & 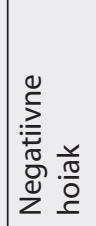 \\
\hline \multicolumn{10}{|l|}{$\begin{array}{c}\text { KEEMIA } \\
(N=220 ; \mathrm{P} \text { ja } \mathrm{T})\end{array}$} \\
\hline \multicolumn{10}{|l|}{$\begin{array}{c}\text { Madal } \\
(N=43 ; 22 \text { ja } 21)\end{array}$} \\
\hline $\begin{array}{c}\text { Keskmine } \\
(N=104 ; 60 \text { ja } 44)\end{array}$ & & $2,36^{*}$ & & & & & & & \\
\hline $\begin{array}{c}\text { Kõrge } \\
(N=73 ; 23 \text { ja } 50)\end{array}$ & & $2,59 *$ & & & & & & & \\
\hline \multicolumn{10}{|l|}{$\begin{array}{c}\text { BIOLOOGIA } \\
(N=220)\end{array}$} \\
\hline $\begin{array}{c}\text { Madal } \\
(N=88 ; 53 \text { ja } 35)\end{array}$ & & & & $2,03^{*}$ & & & & & \\
\hline $\begin{array}{c}\text { Keskmine } \\
(N=85 ; 38 \text { ja } 47)\end{array}$ & & & & $2,19 *$ & & & & & \\
\hline \multicolumn{10}{|l|}{$\begin{array}{c}\text { Kõrge } \\
(N=47 ; 18 \text { ja } 29)\end{array}$} \\
\hline \multicolumn{10}{|l|}{$\begin{array}{l}\text { GEOGRAAFIA } \\
(N=216)\end{array}$} \\
\hline $\begin{array}{c}\text { Madal } \\
(N=17 ; 9 \text { ja } 8)\end{array}$ & & & & & & & & & $3,37^{*}$ \\
\hline $\begin{array}{c}\text { Keskmine } \\
(N=114 ; 51 \text { ja } 63)\end{array}$ & & & & & & & & & $3,27^{*}$ \\
\hline \multicolumn{10}{|l|}{$\begin{array}{c}\text { Kõrge } \\
(N=85 ; 43 \text { ja 42) }\end{array}$} \\
\hline \multicolumn{10}{|l|}{$\begin{array}{l}\text { FÜÜSIKA } \\
(N=192)\end{array}$} \\
\hline $\begin{array}{c}\text { Madal } \\
(N=47 ; 12 \text { ja } 35)\end{array}$ & & & & & $2,50^{*}$ & & & & \\
\hline $\begin{array}{c}\text { Keskmine } \\
(N=101 ; 51 \text { ja } 50)\end{array}$ & & & & & $2,65^{*}$ & & & & \\
\hline $\begin{array}{c}\text { Kõrge } \\
(N=44 ; 23 \text { ja 21) }\end{array}$ & & & & & & & & & \\
\hline
\end{tabular}

Märkused. Punane - madal, oranž - keskmine, roheline - kõrge. $N$ - õpilaste $\operatorname{arv,~} \mathrm{T}$ - tüdrukud, $\mathrm{P}$ - poisid. ${ }^{*}$ klastrite vahel puuduvad ühe õppeaine sees statistiliselt olulised erinevused. 
Erinevalt kõrge motivatsioonimääraga õpilastest on madala motivatsioonimääraga õpilaste huvi kõikides vaatlusalustes klastrites loodusteaduslike teemade õppimise vastu väike (üldkeskmised vahemikus 2,03-2,29). Erandiks on vaid need õpilased, kellel on madal motivatsioonimäär füüsika õppimisel ja kelle huvi loodusnähtuste õppimise vastu on teistesse madala motivatsioonimääraga klastritesse kuuluvate õpilaste omast suurem, jäädes keskmise väärtuse lähedale $(M=2,50)$. Selle klastri eripära seisneb selles, et sinna kuulub tüdrukuid rohkem kui poisse, kuid samal ajal on neil õpilastel kõige negatiivsem hoiak füüsika õppimise suhtes $(M=3,87)$, võrrelduna teiste õpilastega, kes kuuluvad madala motivatsioonimääraga klastritesse.

Keskmise motivatsioonimääraga õpilaste huvid ja motivatsioonilised suundumused varieeruvad rohkem, sõltudes konkreetsest dimensioonist. Näiteks on keskmise motivatsioonimääraga klastritesse kuuluvad õpilased kõige enam huvitatud loodusnähtuste õppimisest, kõige vähem aga abstraktsetest füüsika ja keemiaga seotud teemadest. Taimede temaatika pakub huvi keskmisel määral ja seda nii bioloogia, keemia kui ka füüsika keskmise motivatsioonimääraga klastritesse kuuluvatele õpilastele.

\section{Arutelu}

9. klassi õpilaste huvi õppekavaga määratud loodusteaduslike teemade õppimise vastu ning loodusteaduslike õppeainete õppimisega seotud õpimotivatsiooni pole varem Eestis sellisel kujul uuritud. Küll aga on võimalik praegusi uurimistulemusi kõrvutada teistes riikides tehtud samateemaliste uuringute (nt ROSE) omadega, et osutada põhitendentsidele.

Esimese uurimisküsimusega sooviti välja selgitada, millised kontekstid pakuvad õpilastele ühe ja sama õppekavaga määratud loodusteadusliku teema piires rohkem huvi. Siinse uurimuse tulemused näitavad, et õpilaste huvi loodusteaduslike teemade õppimise vastu sõltub nii õppeainest kui ka teemade esitamise kontekstist. Õpilaste huvides eristusid õppeainespetsiifiliselt selgelt kaks huvi dimensiooni: pinnamood (geograafias) ja taimed (bioloogias). Taimede teemavaldkonnaga seotud $\mathrm{H}$-dimensioon eristus teistest selle poolest, et selles sisaldusid kõik üheksa taimedega seonduvat teemat ning õpilaste huvi oli suurem just personaalses kontekstis esitatud teemade õppimise vastu. Pinnamoe $\mathrm{H}$-dimensioon eristus geograafiaspetsiifilisena ning selles sisaldusid nii ainealases kui ka personaalses kontekstis esitatud teemad. Samamoodi nagu taimede teema puhul, oli õpilaste huvi suurem personaalses kontekstis esitatud pinnavormide teemade vastu. Erinevalt varasemate uuringute tulemustest (Teppo \& Rannikmäe, 2008) ei ilmnenud praegusest tööst, et õpilased tunneksid vähest huvi taimede ehi- 
tusega seonduva vastu, küll aga ilmnes see tendents pinnavormide temaatika puhul. Üks põhjusi, miks õpilased huvituvad rohkem taimede temaatikast, võib olla 2010. aastal tehtud õppekavareform, mis andis suunised kompetentsuspõhiseks õppekava kujundamiseks (Põhikooli riiklik õppekava, 2010). Interdistsiplinaarsesse (mitme õppeainega seotud) huvide dimensiooni kuuluvate tehnoloogiliste rakenduste ja loodusnähtuste puhul ilmnes sarnane tendents nagu taimede ja pinnamoe dimensioonide puhul: personaalses ja sotsiaalses kontekstis esitatud loodusteaduslikud teemad osutusid õpilastele huvipakkuvaks.

Abstraktsuse dimensioonist lähtuvalt eristus analüüsi tulemusel üks H-dimensioon - abstraktsed teemad -, mis sisaldas nii füüsika- kui ka keemiaspetsiifilisi teoreetilisi teemasid, esitatuna vaid ainealases kontekstis. Tulemustest selgus, et see oli ka üks $\mathrm{H}$-dimensioonidest, milles sisalduvate teemade õppimise vastu oli õpilaste huvi kõige väiksem. See võib olla tingitud asjaolust, et kõnealuses $\mathrm{H}$-dimensioonis ei olnud võimalik eristada ainealaste kontekstide kõrval personaalseid ega sotsiaalseid kontekste, mille suhtes oleks õpilased tõenäolisemalt üles näidanud suuremat huvi. Lavoneni jt (2008) uuringust selgus, et kui füüsika- ja keemiateemad esitati personaalses, õpilaste igapäevaeluga seotud kontekstis, siis pakkusid need õpilastele enam huvi kui pelgalt teoreetilised ja ainealased teemad. Peale kontekstuaalse aspekti võib keemia- või füüsikaspetsiifiliste teemade ebahuvitavust seostada ka õpilaste sooliste ja vanuseliste eripäradega (Potvin \& Hasni, 2014; Walpner et al., 2016) ning Eesti kontekstis ka loodusteaduslike óppeainete eraldi õpetamisega alates 8 . klassist.

Teise uurimisküsimuse kaudu sooviti välja selgitada, milliseid soolisi erinevusi esineb õpilaste huvis ja motivatsioonis õppida loodusaineid. Nii nagu huvi dimensioonide korral, eristusid ka motivatsiooni osas viis M-dimensiooni. Kui teine (väärtustamine) ja kolmas (pingutus) dimensioon kattusid sisuliselt Deci ja Ryani (2015) originaalinstrumendi vastavate alaskaalade väidetega, siis esimene (sisemine motivatsioon) ja neljas (negatiivne hoiak) dimensioon on erinevad, moodustudes huvi, enesetõhususe ja autonoomia alaskaalade väidetest. Seega ei saa praegustele uurimistulemustele toetudes eraldi dimensioonidena loodusteaduste kontekstis välja tuua huvi/ meeldivuse, tajutud autonoomia ning kompetentsuse alaskaalat, mis viitab sellele, et esitatud väited on tugevasti omavahel seotud, moodustades ühe M-dimensiooni, mis kirjeldas valimit kõige enam.

Uurimuse tulemused näitavad, et õpilaste huvis ja motivatsioonis õppida loodusaineid esineb soolisi erinevusi. Näiteks pakub taimede ja erinevate loodusnähtustega seotud temaatika statistiliselt olulisel määral rohkem huvi tüdrukutele kui poistele, samas on atomiehituse ja vooluringiga 
seotud teemad enam huvipakkuvad poistele. Sarnased tendentsid ilmnevad ka mitmete teiste uuringute põhjal (Christidou, 2006; Lavonen et al., 2008; Teppo \& Rannikmäe, 2008), osutades kokkuvõttes soospetsiifilistele suundumustele. Taimede teema puhul võib tüdrukute huvi olla seotud personaalse konteksti ning vahetult tajutava (käega katsutava) olukorraga, mis annab õpilastele piisavalt hea ettekujutuse, missugused taimed on, kus need kasvavad või milleks neid kasutatakse. Samas aga ilmnes uurimistulemustest, et aatomiehitus kui abstraktne teema on õpilastele (eelkõige tüdrukutele) ebahuvitav. Põhjuseid võib olla mitmeid alates stereotüüpsetest eripäradest kuni viisini, kuidas õpetaja konkreetset teemat käsitleb. Brophy (2010) soovitab raskete ja abstraktsete teemade mõistmiseks ning õppimise vastu huvi äratamiseks kasutada näiteks mängulisi elemente (rollimängud) ning visualiseerimiseks info- ja kommunikatsioonitehnoloogia vahendeid, loomulikult tuleb rõhutada ka teema olulisust, seostades seda õpilaste igapäevaeluga.

Soolisi erinevusi vaadeldes ilmnes, et tüdrukud pingutavad ja väärtustavad loodusainete õppimisel statistiliselt olulisel määral enam kui poisid. Parajat pingutust nõudev õppimine soodustab sisemise huvi ja motivatsiooni teket (Krapp 2002, 2005), kuid kui pingutus on üle jõu käiv või kui see muutub tuupimiseks, tekitab see õpilastes eduelamuse asemel pigem negatiivseid emotsioone. Positiivne on aga see, et põhikooli lõpuklasside õpilaste hinnangud loodusainete meeldivusele ja huvitavusele on PISA 2006 ja 2015 tulemuste võrdluses (OECD, 2007, 2016) aastatega paranenud. Järelikult on loodusainete õppimises ja õpetamises toimunud oluline muutus, mida võib seostada 2011. aastal vastu võetud uue põhikooli riikliku õppekava rakendumisega. Samas ei saa märkimata jätta, et õpetajal on jätkuvalt oluline, kui mitte kõige olulisem roll õpimotivatsiooni tekkimisel, kujunemisel ja säilitamisel.

Kolmanda uurimisküsimuse kaudu sooviti välja selgitada õpilaste motivatsiooniprofiilid ja nende seos õpilaste huvidega. Võttes aluseks instrumendi motivatsiooni osast neli M-dimensiooni, leiti kokku kaksteist õpilasi iseloomustavat profiili, nii et iga loodusaine (bioloogia, geograafia, keemia ja füüsika) sees moodustus kolm klastrit (kõrge, keskmine ja madala motivatsioonimääraga õpilased), mis erinesid üksteisest nii suuruse (sh poiste ja tüdrukute arvu) kui ka huvi ja õpimotivatsiooni poolest.

Uurimistulemused osutasid tendentsile, mille järgi olid kõrge motivatsioonimääraga õpilased huvitatud loodusteaduste õppimisest kõikides õppeainetes ning erinevalt madala motivatsioonimääraga õpilastest olid nad motiveeritud loodusteadusi õppima. Samas aga iseloomustas keskmise motivatsioonimääraga õpilasi pigem vähene huvi. Seega tuleks artikli 
aluseks oleva uuringu tulemustele tuginedes pöörata loodusainete õpetamisel tähelepanu neile õpilastele, kelle huvi ja motivatsioon õppida loodusaineid on vähene. Kui analüüsida madala motivatsioonimääraga õpilaste huvi konkreetsete loodusteaduslike teemade õppimise vastu, siis ilmneb siiski tendents, et õpilaste igapäevaelu ja sotsiaalse keskkonnaga seotud teemad (nt looduskatastroofid, mürktaimed ja nende mõju organismile) pakuvad neile veidi enam huvi kui teoreetilised ja abstraktsed teemad. Ôpetamise seisukohalt on oluline kasutada madala motivatsioonimääraga õpilaste õpetamisel loodusainete tundides senisest enam huvi tekitavaid õppeülesandeid, pidades silmas konteksti esitamise vormi ning õpilaskeskseid óppemeetodeid (õpilaste aktiivne osalus), mis soodustavad huvi loodusainete õppimise vastu (Teppo \& Rannikmäe, 2008). Seega peale eelnimetatud tegurite mõjutab õpilaste motivatsiooni ka õpetaja oma isiksuse, õpetamiskogemuse ja valitud óppemeetoditega.

Kui võrrelda madala, keskmise ja kõrge motivatsioonimääraga õpilasi ühe loodusteadusliku õppeaine piires, siis ilmneb, et näiteks kõrge motivatsioonimääraga õpilaste klaster keemias on soospetsiifiline - tüdrukuid on selles klastris poole rohkem kui poisse ning seega huvide positiivses suundumuses on määrav roll just tüdrukutel (tabel 8). Samal ajal iseloomustab madala motivatsioonimääraga klastrit bioloogias poiste rohkus. Saadud tulemused on vastupidised autorite varasemate uuringute (Teppo, 2004; Teppo \& Rannikmäe, 2008) tulemustele, mille kohaselt olid tüdrukud enam huvitatud bioloogia ja poisid keemia õppimisest, kuid siinkohal tuleb märkida, et varasemad uuringud ei võtnud arvesse õpilaste motivatsioonierinevustest tingitud huvide eelistusi. Tulemustest selgub ka, et kõige negatiivsem huvide suundumus on neil õpilastel, kes kuuluvad geograafias madala motivatsioonimääraga klastrisse $(N=17)$. Samas on neid õpilasi oluliselt vähem ka bioloogia madala motivatsioonimääraga klastrites, kuhu kuulub 88 õpilast. Kokkuvõttes näitavad uurimistulemused, et õpilaste huvid on ühelt poolt õppeainespetsiifilised ning teiselt poolt mõjutab huve õpilaste motiveerituse määr.

Siinne artikkel erineb varasematest (Bennett et al., 2007; Lavonen et al., 2008; Osborne \& Collins, 2001) selle poolest, et õpilaste huvi erinevate loodusteaduslike teemade õppimise vastu uuriti kompleksselt, nelja loodusteadusliku õppeaine piires ning seega on võimalik teha järeldusi ühe õppeaine põhjal ja võrdluses teistega. Lisaks võimaldas klasteranalüüs eristada õpilaste profiile kolmel tasandil (kõrge, keskmine ja madal) iga loodusteadusliku õppeaine sees, lähtudes õpilaste motivatsioonist õppida kas bioloogiat, geograafiat, keemiat või füüsikat. 


\section{Järeldused}

1. Õpilaste huvi loodusteaduslike teemade õppimise vastu sõltub nii kontekstist kui ka õppeaine spetsiifikast. Kui personaalsete ja sotsiaalsete kontekstidega interdistsiplinaarsed valdkonnad, nagu tehnoloogilised rakendused ja loodusnähtused, osutusid õpilaste jaoks kõige huvipakkuvamaks, siis keemia ja füüsikaga seotud abstraktsed teemad olid nende hinnangul ebahuvitavad. Õppeaine spetsiifika põhjal saab järeldada, et taimede (bioloogia) ja pinnamoega (loodusgeograafia) seotud teemade huvitavus sõltub teema esitamise kontekstist. Eluliste kontekstide kaudu on võimalik näidata õpilastele ka õpitava olulisust ja tähenduslikkust tänapäeva ühiskonnas ning suurendada loodusainete õppimise motivatsiooni.

2. Soolised erinevused ilmnesid nii õpilaste huvis kui ka motivatsioonis õppida loodusaineid. Kui bioloogia ja loodusgeograafiaga seotud temaatika (taimed ja loodusnähtused) pakkusid statistiliselt olulisel määral enam huvi tüdrukutele kui poistele, siis füüsika- ja keemiateemad (nt aatomiehitus ja vooluring) olid statistiliselt olulisel määral rohkem huvipakkuvad poistele. Tüdrukute ja poiste motivatsioonis õppida loodusaineid ilmnes erinevus selles, et tüdrukud väärtustavad loodusaineid kõrgemalt ning väidavad end pingutavat õppimisel statistiliselt olulisel määral enam kui poisid.

3. Lähtudes erinevatest motivatsiooni dimensioonidest (sisemine motivatsioon, väärtustamine, pingutus ja negatiivne hoiak), oli võimalik iga loodusaine sees eristada kolme õpilaste profiili - kõrge, keskmise ja madala motivatsioonimääraga õpilasi, kes erinesid üksteisest kontekstuaalsete huvide ning õpimotivatsiooni poolest.

Artikkel annab ülevaade 9. klassi õpilaste kontekstuaalsetest huvidest ja motivatsioonist õppida loodusaineid, kuid uurimistulemused ei võimalda teha järeldusi loodusainete õpetajate mõju kohta, olgugi et õpetaja roll on määrav õpilaste huvide ja hinnangute kujunemisel. Ainuüksi õpilaste huvi ja motivatsiooniliste suundumuste väljaselgitamisest aga ei piisa, vaid edaspidist uurimist vajab ka see, kuivõrd sarnased või erinevad on õpilaste ja õpetajate üksikasjalikud hinnangud loodusainete õppimise ning õpetamise kohta. Kuivõrd artikkel kajastab vaid 9. klassi õpilaste tulemusi, siis edaspidi on autoritel plaanis võrrelda saadud tulemusi 6. klassi õpilaste omadega, et välja selgitada vanusest tingitud sarnasused ja erinevused. 


\section{Soovitused}

Artiklis esitatud uurimistulemusi saab otseselt rakendada loodusainete tundides: loodusainete õpetajad võiksid senisest julgemalt kasutada personaalseid ja sotsiaalseid kontekste, et õpetada abstraktseid (teoreetilisi) loodusteaduslikke teemasid, äratada nende vastu huvi või seda huvi alal hoida.

\section{Piirangud}

Uurimistulemused ei ole üldistatavad kõikidele Eesti 9. klassi õpilastele, kuna valim ei olnud üldkogumi mõistes piisavalt arvukas.

\section{Tänusõnad}

Uuring on tehtud Eesti Teadusfondi institutsionaalse uurimisprojekti „Nutikad tehnoloogiad ja digitaalne kirjaoskus õppimiskäsituse muutmisel” (IUT34-6) toetusel. Uuringu läbiviijad tänavad õpilasi, õpetajaid ja lapsevanemaid, kes olid nõus andmekogumises osalema.

\section{Kasutatud kirjandus}

Ainley, M., Hidi, S., \& Berndorff, D. (2002). Interest, learning, and the psychological processes that mediate their relationship. Journal of Educational Psychology, 94(3), 545-561. https://doi.org/10.1037/0022-0663.94.3.545

Alebiosu, K. A. (2006). Gender and students' interests in organic chemistry topics at the senior secondary level. Gender and Behavior, 4(1), 522-533. https://doi.org/10.4314/gab.v4i1.23343

Badri, M., Al Mazroui, K., Al Rashedi, A., \& Yang, G. (2016). Variation by gender in Abu Dhabi high school students' interests in physics. Journal of Science Education and Technology, 25(2), 232-243. https://doi.org/10.1007/s10956-015-9589-x

Bandura, A. (2001). Social cognitive theory: An agentic perspective. Annual Review Psychology, 52, 1-26. https://doi.org/10.1146/annurev.psych.52.1.1

Baram-Tsabari, A., \& Kaadni, A. (2009). Gender dependency and cultural independency of science interest in an open and distant science learning environment. International Review of Research in Open and Distributed Learning, 10(2). https://doi.org/10.19173/irrodl.v10i2.591

Baram-Tsabari, A., Sethi, R. J., Bry, L., \& Yarden, A. (2010). Identifying students' interests in biology using a decade of self-generated questions. Eurasia Journal of Mathematics, Science \& Technology Education, 6(1), 63-75.

Bennett, J., Lubben, F., \& Hogarth, S. (2007). Bringing science to life: A synthesis of the research evidence on the effects of context-based and STS approaches to science teaching. Science Education, 91(3), 347-370.

https://doi.org/10.1002/sce.20186 
Betzner, J. P., \& Marek, E. A. (2014). Teacher and student perceptions of earth science and its educational value in secondary schools. Creative Education, 5(11), 10191031. https://doi.org/10.4236/ce.2014.511116

Broman, K., Bernholt, S., \& Parchmann, I. (2015). Analysing task design and students' responses to context-based problems through different analytical frameworks. Research in Science \& Technological Education, 33(2), 143-161. https://doi.org/10.1080/02635143.2014.989495

Broman, K., \& Parchmann, I. (2014). Students' application of chemical concepts when solving chemistry problems in different contexts. Chemistry Education Research and Practice, 15(4), 516-529. https://doi.org/10.1039/C4RP00051J

Brophy, J. (2010). Kuidas ópilasi motiveerida. Käsiraamat ópetajatele. Tallinn: Archimedes.

Chen, A., \& Shen, B. (2004). A web of achieving in physical education: Goals, interest, outside-school activity and learning. Learning and Individual Differences, 14(3), 169-182. https://doi.org/10.1016/j.lindif.2004.02.003

Cheng, Y.-C., \& Yeh, H-Te (2009). From concepts of motivation to its application in instructional design: Reconsidering motivation from an instructional design perspective. British Journal of Educational Technology, 40(4), 597-605. https://doi.org/10.1111/j.1467-8535.2008.00857.x

Christidou, V. (2006). Greek students' science related interests and experiences: Gender differences and correlations. International Journal of Science Education, 28(10), 1181-1199. https://doi.org/10.1080/09500690500439389

Dawson, C. (2000). Upper primary boys' and girls' interests in science: Have they changed since 1980? International Journal of Science Education, 22(6), 557-570. https://doi.org/10.1080/095006900289660

Deci, E. L., \& Ryan, R. M. (2000). The "what" and "why" of goal pursuits: Human needs and the self-determination of behavior. Psychological Inquiry, 11(4), 227268. https://doi.org/10.1207/S15327965PLI1104_01

Deci, E. L., \& Ryan, R. M. (2002). Self-determination research: Reflections and future directions. In E. L. Deci \& R. M. Ryan (Eds.), Handbook of self-determination research (pp. 431-441). Rochester: University of Rochester Press.

Deci, E. L., \& Ryan, R. M. (2015). SDT: Questionnaires: Intrinsic Motivation Inventory (IMI). Retrieved from http://selfdeterminationtheory.org/intrinsic-motivation-inventory/.

De Jong, O. (2006). Making chemistry meaningful: Conditions for successful context-based teaching. Education Quimica, 17, 215-221.

DeWitt, J., \& Archer, L. (2015). Who aspires to a science career? A comparison of survey responses from primary and secondary school students. International Journal of Science Education, 37(13), 2170-2192. https://doi.org/10.1080/09500693.2015.1071899

Dohn, N. B. (2011). Upper secondary students' situational interest: A case study of the role of a zoo visit in a biology class. International Journal of Science Education, 35(16), 2732-2751. https://doi.org/10.1080/09500693.2011.628712

Eesti elukestva õppe strateegia 2020 (2014). Haridus- ja Teadusministeerium, Eesti Koostöö Kogu, sihtasutus Eesti Haridusfoorum. Külastatud aadressil https:/hm.ee/sites/default/files/strateegia2020.pdf. 
Fensham, P. J. (2004). Increasing the relevance of science and technology education for all students in the 21st century. Science Education International, 15(1), 7-27.

Gardner, P. L., \& Tamir, P. (1989). Interest in biology. Part I: A multidimensional construct. Journal of Research in Science Teaching, 26(5), 409-423. https://doi.org/10.1002/tea.3660260506

Gilbert, J. K. (2006). On the nature of context in chemical education. International Journal of Science Education, 28(9), 957-976. https://doi.org/10.1080/09500690600702470

Gilbert, J. K., Bulte, A. M. W., \& Pilot, A. (2011). Concept development and transfer in context-based science education. International Journal of Science Education, 33(6), 817-837. https://doi.org/10.1080/09500693.2010.493185

Glynn, S. M., Brickman, P., Armstrong, N., \& Taasoobshirazi, G. (2011). Science Motivation Questionnaire II: Validation with science majors and nonscience majors. Journal of Research in Science Teaching, 48(10), 1159-1176. https://doi.org/10.1002/tea.20442

Glynn, S. M., \& Koballa, T. R., Jr. (2006). Motivation to learn college science. In J. J. Mintzes \& W. H. Leonard (Eds.), Handbook of college science teaching (pp. 25-32). Arlington: National Science Teachers Association Press.

Glynn, S. M., Taasoobshirazi, G., \& Brickman, P. (2009). Science Motivation Questionnaire: Construct validation with nonscience majors. Journal of Research in Science Teaching, 46(2), 127-146. https://doi.org/10.1002/tea.20267

Hagay, G., Baram-Tsabari, A., Ametller, J., Cakmakci, G., Lopes, B., Moreira, A., \& Pedrosa-de-Jesus, H. (2013). The generalizability of students' interests in biology across gender, country and religion. Research in Science Education, 43(3), 895919. https://doi.org/10.1007/s11165-012-9289-y

Hair, J. F., Jr., William, C. B., Babin, B. J., \& Anderson, R. E. (2010). Multivariate data analysis (7th ed.). Upper-Saddle River: Pearson Education.

Harp, S. F., \& Mayer, R. E. (1997). The role of interest in learning from scientific text and illustrations: On the distinction between emotional interest and cognitive interest. Journal of Educational Psychology, 89(1), 92-102. https://doi.org/10.1037/0022-0663.89.1.92

Hidi, S. (1990). Interest and its contribution as a mental resource for learning. Review of Educational Research, 60(4), 549-571. https://doi.org/10.3102/00346543060004549

Hidi, S. (2000). An interest researcher's perspective: The effects of extrinsic and intrinsic factors on motivation. In C. Sansone \& J. M. Harackiewicz (Eds.), Intrinsic motivation: Controversies and new directions (pp. 309-339). New York: Academic Press. https://doi.org/10.1016/B978-012619070-0/50033-7

Hidi, S. (2001). Interest, reading, and learning: Theoretical and practical considerations. Educational Psychology Review, 13(3), 191-209. https://doi.org/10.1023/A:1016667621114

Hidi, S., \& Harackiewicz, J. M. (2000). Motivating the academically unmotivated: A critical issue for the 21st century. Review of Educational Research, 70(2), 151179. https://doi.org/10.3102/00346543070002151

Hidi, S., \& Renninger, K. A. (2006). The four-phase model of interest development. Educational Psychologist, 41(2), 111-127. https://doi.org/10.1207/s15326985ep4102_4 
Hidi, S., Renninger, K. A., \& Krapp, A. (2004). Interest, a motivational variable that combines affective and cognitive functioning. In D. Y. Dai \& R. J. Sternberg (Eds.), Motivation, emotion, and cognition: Integrative perspectives on intellectual functioning and development (pp. 89-115). Mahwah: Lawrence Erlbaum Associates.

Hong, J.-L., Shim, K.-C., \& Chang, N.-K. (1998). A study of Korean middle school students' interests in biology and their implications for biology education. International Journal of Science Education, 20(8), 989-999.

https://doi.org/10.1080/0950069980200806

Häussler, P., \& Hoffmann, L. (2002). An intervention study to enhance girls' interest, self-concept, and achievement in physics classes. Journal of Research in Science Teaching, 39(9), 870-888. https://doi.org/10.1002/tea.10048

King, D. (2012). New perspectives on context-based chemistry education: Using a dialectical sociocultural approach to view teaching and learning. Studies in Science Education, 48(1), 51-87. https://doi.org/10.1080/03057267.2012.655037

Krapp, A. (1999). Interest, motivation and learning: An educational-psychological perspective. European Journal of Psychology of Education, 14(1), 23-40. https://doi.org/10.1007/BF03173109

Krapp, A. (2002). An educational-psychological theory of interest and its relation to SDT. In E. L. Deci \& R. M. Ryan (Eds.), Handbook of self-determination research (pp. 405-427). Rochester: University of Rochester Press.

Krapp, A. (2005). Basic needs and the development of interest and intrinsic motivational orientations. Learning and Instruction, 15(5), 381-395. https://doi.org/10.1016/j.learninstruc.2005.07.007

Krapp, A., Hidi, S., \& Renninger, K. A. (1992). Interest, learning and development. In K. Renninger, S. Hidi, \& A. Krapp (Eds.), The role of interest in learning and development (pp. 3-25). Hillsdale: Erlbaum.

Krapp, A., \& Prenzel, M. (2011). Research on interest in science: Theories, methods, and findings. International Journal of Science Education, 33(1), 27-50. https://doi.org/10.1080/09500693.2010.518645

Larson, R. W. (2000). Toward a psychology of positive youth development. American Psychologist, 55(1), 170-183. https://doi.org/10.1037/0003-066X.55.1.170

Lavonen, J., Gedrovics, J., Byman, R., Meisalo, V., Juuti, K., \& Uitto, A. (2008). Students' motivational orientations and career choice in science and technology: A comparative investigation in Finland and Latvia. Journal of Baltic Science Education, 7(2), 86-102.

Lepper, M. R., Corpus, J. H., \& Iyengar, S. S. (2005). Intrinsic and extrinsic motivational orientations in the classroom: Age differences and academic correlates. Journal of Educational Psychology, 97(2), 184-196. https://doi.org/10.1037/0022-0663.97.2.184

Levitt, K. E. (2001). An analysis of elementary teachers' beliefs regarding the teaching and learning of science. Science Education, 86(1), 1-22. https://doi.org/10.1002/sce.1042

Locke, E. A., \& Latham, G. P. (2006). New directions in goal-setting theory. Current Directions in Psychological Science, 15(5), 265-268. https://doi.org/10.1111/j.1467-8721.2006.00449.x

Maehr, M. L., \& Meyer, H. A. (1997). Understanding motivation and schooling: Where we've been, where we are, and where we need to go. Educational Psychology Review, 9(4), 371-409. https://doi.org/10.1023/A:1024750807365 
Matthews, B. (2004). Promoting emotional literacy, equity and interest in science lessons for 11-14 year olds; the 'Improving Science and Emotional Development' project. International Journal of Science Education, 26(3), 281-308. https://doi.org/10.1080/0950069032000097406

Merenda, P. F. (1997). Methods, plainly speaking: A guide to the proper use of factor analysis in the conduct and reporting of research: Pitfalls to avoid. Measurement and Evaluation in Counseling and Development, 30(3), 156-164.

OECD (2007). PISA 2006. Science competencies for tomorrow's word. Volume I: Analysis. Paris: OECD Publishing. Retrieved from http://www.oecd-ilibrary.org/docserver/ download/9807011e.pdf? expires $=1482159352 \& \mathrm{id}=\mathrm{id} \&$ accname=guest $\&$ checksu $\mathrm{m}=05 \mathrm{D} 0789 \mathrm{~B} 67 \mathrm{C} 3 \mathrm{C} 0 \mathrm{~A} 68 \mathrm{C} 9 \mathrm{FB} 0923 \mathrm{E} 0 \mathrm{~A} 2209$.

OECD (2016). PISA 2015 results (Vol. 1). Excellence and equity in education. Paris: OECD Publishing. Retrieved from http://www.keepeek.com/Digital-Asset-Management/oecd/education/pisa-2015-results-volume-i_9789264266490-en\#.WFfpYVN96Uk.

Osborne, J. W. (2015). What is rotating in exploratory factor analysis? Practical assessment, Research \& Evaluation, 20(2). Retrieved from http://pareonline.net/getvn.asp? $\mathrm{v}=20 \& \mathrm{n}=2$.

Osborne, J., \& Collins, S. (2001). Pupils' views of the role and value of the science curriculum: a focus group study. International Journal of Science Education, 23(5), 441-467. https://doi.org/10.1080/09500690010006518

Osborne, J., Simon, S., \& Collins, S. (2003). Attitudes towards science: A review of the literature and its implications. International Journal of Science Education, 25(9), 1049-1079. https://doi.org/10.1080/0950069032000032199

Pilot, A., \& Bulte, A. M. W. (2006). The use of "contexts" as a challenge for the chemistry curriculum: Its successes and the need for further development and understanding. International Journal of Science Education, 28(9), 1087-1112. https://doi.org/10.1080/09500690600730737

PISA 2015 Eesti tulemused: Eesti 15-aastaste õpilaste teadmised ja oskused matemaatikas, funktsionaalses lugemises ja loodusteadustes (2016). Tallinn: Innove. Külastatud aadressil

https://www.hm.ee/sites/default/files/pisa_2015_final_veebivaatamiseks_0.pdf.

Potvin, P., \& Hasni, A. (2014). Analysis of the decline in interest towards school science and technology from grades 5 through 11. Journal of Science Education and Technology, 23(6), 784-802. https://doi.org/10.1007/s10956-014-9512-x

Prenzel, M. (1992). The selective persistence of interest. In K. A. Renninger, S. Hidi, \& A. Krapp (Eds.), The role of interest in learning and development (pp. 71-98). Hillsdale: Erlbaum.

Põhikooli riiklik õppekava (2011). Riigi Teataja I, 29.08.2014, 20. Külastatud aadressil https://www.riigiteataja.ee/akt/114012011001.

Ramsden, J. M. (1998). Mission impossible? Can anything be done about attitudes to science? International Journal of Science Education, 20(2), 125-137. https://doi.org/10.1080/0950069980200201

Reeve, J., \& Jang, H. (2006). What teachers say and do to support students' autonomy during a learning activity. Journal of Educational Psychology, 98(1), 209-218. https://doi.org/10.1037/0022-0663.98.1.209 
Reid, N., \& Skryabina, E. (2003). Gender and physics. International Journal of Science Education, 25(4), 509-536. https://doi.org/10.1080/0950069022000017270

Renninger, K. A. (1990). Children's play interests, representations, and activity. In R. Fivush \& J. A. Hudson (Eds.), Knowing and remembering in young children (Emory Cognition Series, Vol. 3, pp. 127-165). New York: Cambridge University Press.

Renninger, K. A. (2000). Individual interest and its implications for understanding intrinsic motivation. In I. C. Sansone \& J. M. Harackiewicz (Eds.), Intrinsic and extrinsic motivation: The search for optimal motivation and performance (pp. 375407). San Diego: Academic Press.

https://doi.org/10.1016/B978-012619070-0/50035-0

Ryan, R. M., \& Deci, E. L. (2000). Intrinsic and extrinsic motivations: Classic definitions and new directions. Contemporary Educational Psychology, 25(2), 54-67. https://doi.org/10.1006/ceps.1999.1020

Salta, K., \& Tzougraki, C. (2004). Attitudes toward chemistry among 11 th grade students in high schools in Greece. Science Education, 88(4), 535-547. https://doi.org/10.1002/sce.10134

Schraw, G., \& Lehman, S. (2001). Situational interest: A review of the literature and directions for future research. Educational Psychology Review, 13(1), 23-52. https://doi.org/10.1023/A:1009004801455

Schreiner, C., \& Sjøberg, S. (2004). Sowing the seeds of ROSE. Background, rationale, questionnaire development and data collection for ROSE (The Relevance of Science Education) - a comparative study of students' views of science and science education. Acta Didactica, 4. Oslo: University of Oslo.

Schreiner, C., \& Sjøberg, S. (2007). Science education and young people's identity construction: Two mutually incompatible projects? In D. Corrigan, J. Dillon, \& R. Gunstone (Eds.), The re-emergence of values in the science education (pp. 231248). Rotterdam: Sense.

Silvia, P. J. (2006). Exploring the psychology of interest. New York: Oxford University Press.

Sjøberg, S., \& Schreiner, C. (2008). Concerns for the environment. Data from ROSE (The Relevance of Science Education). Retrieved from http://www.roseproject. no/network/countries/norway/eng/nor-sjoberg-env2008.pdf.

Stevens, J. P. (2009). Applied multivariate statistics for the social sciences (5th ed.). New York: Routledge.

Teppo, M. (2004). Grade nine students' opinions relating to the relevance of science education (Master's thesis). Tartu: University of Tartu. Retrieved from http:// dspace.ut.ee/bitstream/handle/10062/1057/Teppo.pdf? sequence=5\&isAllowed=y.

Teppo, M., \& Rannikmäe, M. (2008). Paradigm shift for teachers: More relevant science teaching. In J. Holbrook, M. Rannikmäe, P. Reiska, \& P. Ilsley (Eds.), The need for a paradigm shift in science education for post-Soviet societies (pp. 25-46). Frankfurt am Main: Peter Lang.

Trumper, R. (2006). Factors affecting junior high school students' interest in physics. Journal of Science Education and Technology, 15(1), 47-58. https://doi.org/10.1007/s10956-006-0355-6 
Van Aalsvoort, J. (2004). Logical positivism as a tool to analyse the problem of chemistry's lack of relevance in secondary school chemical education. International Journal of Science Education, 26(9), 1151-1168. https://doi.org/10.1080/0950069042000205369

Walper, L. M., Pollmeier, K., Lange, K., Kleickmann, T., \& Möller, K. (2016). From general science teaching to discipline-specific science teaching: Physics instruction and students' subject-related interest levels during the transition from primary to secondary school. In N. Papadouris, A. Hadjigeorgiou, \& C. Constantinou (Eds.), Insights from research in science teaching and learning: Selected papers from the ESERA 2013 conference (Vol. 2, pp. 271-288). Springer International Publishing. https://doi.org/10.1007/978-3-319-20074-3_18 
Lisa 1. Õpilaste huvi ja motivatsiooni kirjeldavad klastrid õppeainete kaupa

Tabel 1. Õpilasi kirjeldavad klastrid keemias ning huvi ja motivatsiooni dimensioonide erinevused klastriti

\begin{tabular}{|c|c|c|c|c|c|c|c|c|c|c|c|}
\hline \multirow{4}{*}{$\begin{array}{l}\text { Huvi ja } \\
\text { motivatsiooni } \\
\text { dimensioonid }\end{array}$} & \multicolumn{6}{|c|}{ Motivatsioonimäär } & & & \multirow{2}{*}{\multicolumn{3}{|c|}{$\begin{array}{c}\text { Klastritevahelised } \\
\text { erinevused, p-väärtused }\end{array}$}} \\
\hline & \multirow{2}{*}{\multicolumn{2}{|c|}{$\begin{array}{l}\text { Madal } \\
(N=88)\end{array}$}} & \multirow{2}{*}{\multicolumn{2}{|c|}{$\begin{array}{l}\text { Keskmine } \\
(N=85)\end{array}$}} & \multirow{2}{*}{\multicolumn{2}{|c|}{$\begin{array}{c}\text { Kõrge } \\
(N=47)\end{array}$}} & \multirow{2}{*}{\multicolumn{2}{|c|}{ Kokku }} & & & \\
\hline & & & & & & & & & kesk- & kesk- & madal \\
\hline & $M$ & $S D$ & $M$ & $S D$ & $M$ & $S D$ & $M$ & $S D$ & madal & kõrge & kõrge \\
\hline $\begin{array}{l}\text { Tehnoloogilised } \\
\text { rakendused }\end{array}$ & 1,79 & 0,72 & 2,34 & 0,68 & 2,61 & 0,79 & 2,32 & 0,78 & 0,000 & 0,020 & 0,000 \\
\hline Pinnavormid & 1,90 & 0,79 & 2,36 & 0,70 & 2,59 & 0,82 & 2,35 & 0,80 & 0,000 & 0,067 & 0,000 \\
\hline Taimed & 1,98 & 0,74 & 2,54 & 0,67 & 2,81 & 0,78 & 2,52 & 0,77 & 0,000 & 0,024 & 0,000 \\
\hline $\begin{array}{l}\text { Abstraktsed } \\
\text { teemad }\end{array}$ & 1,69 & 0,71 & 2,19 & 0,70 & 2,68 & 0,74 & 2,25 & 0,79 & 0,000 & 0,000 & 0,000 \\
\hline $\begin{array}{l}\text { Loodus- } \\
\text { nähtused }\end{array}$ & 2,22 & 0,74 & 2,67 & 0,66 & 2,91 & 0,75 & 2,66 & 0,75 & 0,000 & 0,013 & 0,000 \\
\hline $\begin{array}{l}\text { Sisemine } \\
\text { motivatsioon }\end{array}$ & 1,71 & 0,63 & 3,03 & 0,52 & 4,18 & 0,49 & 3,15 & 1,02 & 0,000 & 0,000 & 0,000 \\
\hline $\begin{array}{l}\text { Loodusainete } \\
\text { väärtustamine }\end{array}$ & 2,29 & 0,73 & 3,18 & 0,46 & 3,83 & 0,45 & 3,22 & 0,75 & 0,000 & 0,000 & 0,000 \\
\hline Pingutus & 2,06 & 0,82 & 3,20 & 0,68 & 3,95 & 0,65 & 3,22 & 0,96 & 0,000 & 0,000 & 0,000 \\
\hline $\begin{array}{l}\text { Negatiivne } \\
\text { hoiak }\end{array}$ & 3,64 & 0,85 & 3,17 & 0,61 & 2,52 & 0,82 & 3,05 & 0,84 & 0,000 & 0,000 & 0,000 \\
\hline
\end{tabular}


Tabel 2. Õpilasi kirjeldavad klastrid bioloogias ning huvi ja motivatsiooni dimensioonide erinevused klastriti

\begin{tabular}{|c|c|c|c|c|c|c|c|c|c|c|c|}
\hline \multirow{4}{*}{$\begin{array}{l}\text { Huvi ja } \\
\text { motivatsiooni } \\
\text { dimensioonid }\end{array}$} & \multicolumn{6}{|c|}{ Motivatsioonimäär } & & & \multirow{2}{*}{\multicolumn{3}{|c|}{$\begin{array}{c}\text { Klastritevahelised } \\
\text { erinevused, p-vä̈̈rtusec }\end{array}$}} \\
\hline & \multirow{2}{*}{\multicolumn{2}{|c|}{$\begin{array}{c}\text { Madal } \\
(N=88)\end{array}$}} & \multirow{2}{*}{\multicolumn{2}{|c|}{$\begin{array}{c}\text { Keskmine } \\
(N=85)\end{array}$}} & \multirow{2}{*}{\multicolumn{2}{|c|}{$\begin{array}{c}\text { Kõrge } \\
(N=47)\end{array}$}} & \multirow{2}{*}{\multicolumn{2}{|c|}{ Kokku }} & & & \\
\hline & & & & & & & & & kesk- & kesk- & madal \\
\hline & $M$ & $S D$ & $M$ & $S D$ & $M$ & $S D$ & $M$ & $S D$ & madal & kõrge & kõrge \\
\hline $\begin{array}{l}\text { Tehnoloogilised } \\
\text { rakendused }\end{array}$ & 2,09 & 0,76 & 2,32 & 0,68 & 2,83 & 0,64 & 2,34 & 0,75 & 0,036 & 0,000 & 0,000 \\
\hline Pinnavormid & 1,97 & 0,75 & 2,35 & 0,78 & 2,94 & 0,71 & 2,33 & 0,83 & 0,001 & 0,000 & 0,000 \\
\hline Taimed & 2,09 & 0,73 & 2,55 & 0,70 & 3,12 & 0,65 & 2,49 & 0,80 & 0,000 & 0,000 & 0,000 \\
\hline $\begin{array}{l}\text { Abstraktsed } \\
\text { teemad }\end{array}$ & 2,03 & 0,78 & 2,19 & 0,83 & 2,66 & 0,83 & 2,22 & 0,84 & 0,202 & 0,004 & 0,000 \\
\hline Loodusnähtused & 2,29 & 0,78 & 2,78 & 0,64 & 3,18 & 0,53 & 2,67 & 0,76 & 0,000 & 0,000 & 0,000 \\
\hline $\begin{array}{l}\text { Sisemine moti- } \\
\text { vatsioon }\end{array}$ & 2,83 & 0,54 & 3,95 & 0,49 & 4,29 & 0,68 & 3,58 & 0,83 & 0,000 & 0,001 & 0,000 \\
\hline $\begin{array}{l}\text { Loodusainete } \\
\text { väärtustamine }\end{array}$ & 2,88 & 0,60 & 3,71 & 0,38 & 4,15 & 0,38 & 3,47 & 0,70 & 0,000 & 0,000 & 0,000 \\
\hline Pingutus & 2,59 & 0,70 & 3,14 & 0,49 & 4,41 & 0,47 & 3,19 & 0,89 & 0,000 & 0,000 & 0,000 \\
\hline Negatiivne hoiak & 3,30 & 0,76 & 2,49 & 0,56 & 2,97 & 0,79 & 2,92 & 0,78 & 0,000 & 0,001 & 0,000 \\
\hline
\end{tabular}


Tabel 3. Õpilasi kirjeldavad klastrid geograafias ning huvi ja motivatsiooni dimensioonide erinevused klastriti

\begin{tabular}{|c|c|c|c|c|c|c|c|c|c|c|c|}
\hline \multirow{4}{*}{$\begin{array}{l}\text { Huvi ja } \\
\text { motivatsiooni } \\
\text { dimensioonid }\end{array}$} & \multicolumn{6}{|c|}{ Motivatsioonimäär } & & & \multirow{2}{*}{\multicolumn{3}{|c|}{$\begin{array}{c}\text { Klastritevahelised } \\
\text { erinevused, p-väärtused }\end{array}$}} \\
\hline & \multirow{2}{*}{\multicolumn{2}{|c|}{$\begin{array}{c}\text { Madal } \\
(N=17)\end{array}$}} & \multirow{2}{*}{\multicolumn{2}{|c|}{$\begin{array}{l}\text { Keskmine } \\
(N=114)\end{array}$}} & \multirow{2}{*}{\multicolumn{2}{|c|}{$\begin{array}{c}\text { Kõrge } \\
(N=85)\end{array}$}} & \multirow{2}{*}{\multicolumn{2}{|c|}{ Kokku }} & & & \\
\hline & & & & & & & & & kesk- & kesk- & madal \\
\hline & $M$ & $S D$ & $M$ & $S D$ & $M$ & $S D$ & $M$ & $S D$ & madal & kórge & kõrge \\
\hline $\begin{array}{l}\text { Tehnoloogilised } \\
\text { rakendused }\end{array}$ & 1,66 & 0,80 & 2,10 & 0,62 & 2,49 & 0,64 & 2,22 & 0,68 & 0,004 & 0,000 & 0,000 \\
\hline Pinnavormid & 1,62 & 0,81 & 2,07 & 0,65 & 2,61 & 0,65 & 2,24 & 0,73 & 0,005 & 0,000 & 0,000 \\
\hline Taimed & 1,61 & 0,77 & 2,28 & 0,64 & 2,68 & 0,74 & 2,38 & 0,75 & 0,000 & 0,000 & 0,000 \\
\hline $\begin{array}{l}\text { Abstraktsed } \\
\text { teemad }\end{array}$ & 1,46 & 0,76 & 2,02 & 0,68 & 2,48 & 0,78 & 2,16 & 0,78 & 0,001 & 0,000 & 0,000 \\
\hline $\begin{array}{l}\text { Loodus- } \\
\text { nähtused }\end{array}$ & 2,01 & 0,91 & 2,49 & 0,63 & 2,86 & 0,61 & 2,60 & 0,69 & 0,004 & 0,000 & 0,000 \\
\hline $\begin{array}{l}\text { Sisemine } \\
\text { motivatsioon }\end{array}$ & 2,25 & 0,83 & 3,09 & 0,48 & 4,12 & 0,50 & 3,43 & 0,79 & 0,000 & 0,000 & 0,000 \\
\hline $\begin{array}{l}\text { Loodusainete } \\
\text { väärtustamine }\end{array}$ & 2,59 & 0,65 & 3,31 & 0,48 & 3,84 & 0,41 & 3,46 & 0,59 & 0,000 & 0,000 & 0,000 \\
\hline Pingutus & 1,37 & 0,39 & 2,97 & 0,52 & 3,66 & 0,75 & 3,12 & 0,86 & 0,000 & 0,000 & 0,000 \\
\hline $\begin{array}{l}\text { Negatiivne } \\
\text { hoiak }\end{array}$ & 3,37 & 1,21 & 3,27 & 0,59 & 2,60 & 0,75 & 3,01 & 0,79 & 0,261 & 0,000 & 0,000 \\
\hline
\end{tabular}


Tabel 4. Õpilasi kirjeldavad klastrid füüsikas ning huvi ja motivatsiooni dimensioonide erinevused klastriti

\begin{tabular}{|c|c|c|c|c|c|c|c|c|c|c|c|}
\hline \multirow{4}{*}{$\begin{array}{l}\text { Huvi ja } \\
\text { motivatsiooni } \\
\text { dimensioonid }\end{array}$} & \multicolumn{6}{|c|}{ Motivatsioonimäär } & & & \multirow{2}{*}{\multicolumn{3}{|c|}{$\begin{array}{c}\text { Klastritevahelised } \\
\text { erinevused, p-väärtused }\end{array}$}} \\
\hline & \multirow{2}{*}{\multicolumn{2}{|c|}{$\begin{array}{l}\text { Madal } \\
(N=47)\end{array}$}} & \multirow{2}{*}{\multicolumn{2}{|c|}{$\begin{array}{l}\text { Keskmine } \\
(N=101)\end{array}$}} & \multirow{2}{*}{\multicolumn{2}{|c|}{$\begin{array}{c}\text { Kõrge } \\
(N=44)\end{array}$}} & \multirow{2}{*}{\multicolumn{2}{|c|}{ Kokku }} & & & \\
\hline & & & & & & & & & kesk- & kesk- & madal \\
\hline & $M$ & $S D$ & $M$ & $S D$ & $M$ & $S D$ & $M$ & $S D$ & madal & kõrge & kõrge \\
\hline $\begin{array}{l}\text { Tehnoloogilised } \\
\text { rakendused }\end{array}$ & 2,02 & 0,64 & 2,28 & 0,66 & 2,71 & 0,75 & 2,32 & 0,71 & 0,014 & 0,000 & 0,000 \\
\hline Pinnavormid & 1,99 & 0,73 & 2,27 & 0,69 & 2,73 & 0,76 & 2,31 & 0,76 & 0,014 & 0,000 & 0,000 \\
\hline Taimed & 2,11 & 0,66 & 2,48 & 0,61 & 2,98 & 0,78 & 2,50 & 0,73 & 0,001 & 0,000 & 0,000 \\
\hline $\begin{array}{l}\text { Abstraktsed } \\
\text { teemad }\end{array}$ & 1,69 & 0,72 & 2,23 & 0,69 & 2,86 & 0,83 & 2,24 & 0,83 & 0,000 & 0,000 & 0,000 \\
\hline $\begin{array}{l}\text { Loodus- } \\
\text { nähtused }\end{array}$ & 2,50 & 0,78 & 2,65 & 0,61 & 3,03 & 0,66 & 2,70 & 0,69 & 0,234 & 0,001 & 0,001 \\
\hline $\begin{array}{l}\text { Sisemine } \\
\text { motivatsioon }\end{array}$ & 2,08 & 0,57 & 3,32 & 0,45 & 4,32 & 0,59 & 3,24 & 0,93 & 0,000 & 0,000 & 0,000 \\
\hline $\begin{array}{l}\text { Loodusainete } \\
\text { väärtustamine }\end{array}$ & 2,75 & 0,73 & 3,42 & 0,46 & 4,15 & 0,47 & 3,43 & 0,72 & 0,000 & 0,000 & 0,000 \\
\hline Pingutus & 2,85 & 1,03 & 3,17 & 0,59 & 4,36 & 0,60 & 3,36 & 0,91 & 0,009 & 0,000 & 0,000 \\
\hline $\begin{array}{l}\text { Negatiivne } \\
\text { hoiak }\end{array}$ & 3,87 & 0,78 & 2,95 & 0,61 & 2,93 & 1,14 & 3,17 & 0,89 & 0,000 & 0,000 & 0,000 \\
\hline
\end{tabular}




\title{
Grade nine students' learning interests towards science topics presented in different contexts and their motivation to learn science
}

\author{
Moonika Teppo ${ }^{\text {a1 }}$, Helen Semilarskia, \\ Regina Soobard ${ }^{\mathrm{a}}$, Miia Rannikmäe ${ }^{\mathrm{a}}$ \\ ${ }^{a}$ Centre for Science Education, University of Tartu
}

\section{Summary}

\section{Introduction}

Today's society needs active citizens who appreciate education, especially learning at school. If students feel that subjects such as science are valuable and meaningful for them, they are more likely to use their acquired knowledge and skills in deciding their future career choices. The PISA 2006 international comparative study, in which the main area tested is science, shows that only $16 \%$ of Estonian 15-year-old students wish to relate their future career with science-related disciplines (OECD, 2007). When comparing the PISA 2006 and 2015 results, it is evident that there is a statistically significant increase (7.8\%) in students who are interested in choosing science-related future careers (OECD, 2016; PISA 2015 Eesti tulemused, 2016).

The investigation of students' interest and motivation towards science learning is an important issue in science education, as well as at the political level. Findings from the last decade (2000-2009) indicate that learning science at school is irrelevant and less related to students' everyday life and social environment (OECD, 2007; Osborne \& Collins, 2001). While recent studies, such as PISA 2015, show a tendency for Estonian 15-yearold students' interest towards learning science to have increased, the PISA 2015 survey also indicated that $37 \%$ of respondents (more girls than boys) are not interested in studying science. Based on this, it is suggested still necessary to find ways to increase students' interest and motivation towards science learning, especially where students have minimal or no interest. Furthermore, despite these contradictory results, little has been studied about how science content, presented in different contexts, affects students'

Centre for Science Education, University of Tartu, Vanemuise 46, 51014 Tartu, Estonia; moonika.teppo@ut.ee 
curriculum-related science interest within four science subjects (biology, earth science, chemistry, and physics).

The main purpose of the current study is to determine contexts in which grade nine students have greater interest and motivation to learn within the four science subjects.

More specifically the following research questions are put forward:

1. What type of contexts invokes a wider cross-section of students to be interested in learning science subjects with respect to an individual topic?

2. To what degree are there gender differences in students' interests and motivation to learn towards science topics when presented in different contexts?

3. What kind of students' motivational profiles can be identified?

\section{Methodology}

The research data were collected as part of a larger-scale study, conducted in spring 2016. The sample for the study was composed of 848 ninth grade students, of whom 446 were girls and 402 boys, from 46 schools all over Estonia. Students completed a questionnaire electronically, either in a school computer class, or with tablets.

This study used two components of a larger, more complex instrument, which were associated with interest towards various science contexts and motivation towards science subjects. The interest part of the instrument consisted of 36 science topics, presented in different contexts so that within every science subject (biology, earth science/geography, chemistry and physics) there were nine topics put forward in 3 contexts - content-related, scientific applications related and a socio-scientific problem as the context. The subject areas chosen were plants (in biology); Earth, internal structure and relief (in geography); atomic structure, organic compounds and inorganic compounds (in chemistry); and optics, mechanics and electricity (in physics) - all based both on the content indicated in the Estonian basic school science curricula (2010) and previous research results (Teppo, 2004; Teppo \& Rannikmäe, 2008).

Students' motivation to science learning was measured using a modified Intrinsic Motivation Inventory Instrument (Deci \& Ryan, 2015), with the following five out of seven sub-scales: interest/enjoyment, self-efficacy, perceived autonomy, effort/importance and value/ usefulness. All statements within the interest part were presented using a 4-point Likert scale (1-not 
interested ... 4-very interested) and for the motivation part a 5-point Likert scale (1-not agree ... 5-agree) was used. The instrument was piloted before use and validated by experts.

Statistical analysis was carried out using SPSS 23.0. Means $(M)$ and standard deviations (SD) were calculated for each item, or group of items (latent variables). The Independent Samples $t$-test was used to determine statistically significant differences between boys and girls. To describe students' interests and motivation, Principal Component Analysis with Varimax Rotation was performed. $K$-means cluster analysis was carried out for identifying students' motivational profiles.

\section{Results and discussion}

\section{Students' interests and motivation in learning science}

Within the interest part, principal component analysis resulted in five components (future used interest dimensions), describing the contextual nature of interest in science learning. The interest, $(\mathrm{H})$-dimensions, described altogether $66.1 \%$ of the variance of the sample, which were identified as: technological applications, relief, plants, abstract topics and natural phenomena.

Results of the study showed that the students' interests depended both on the context and science subject. Subjects specifically appeared in two $\mathrm{H}$-dimensions - relief (geography) and plants (biology). The results indicated that the students were more interested in these topics when they were presented in personal or social contexts. In contrast to previous studies (Teppo \& Rannikmäe, 2008), the outcomes did not reveal students' low interest in plant-related topics, but towards reliefs. Students' high interest in plants can be explained by the curriculum reform carried out in 2010, which provided guidance for a competence-based curriculum design (Põhikooli riiklik õppekava, 2011). In comparison to all H-dimensions, students were more interested in learning about interdisciplinary natural phenomena, presented in personal and social contexts. The least interesting topics were those content-related and abstract in chemistry and physics (atom structure, electric circuits and its components). One reason for this could be the fact that within abstract dimensions we could not distinguish between different contexts and only content-related items were included. According to the context, reasons could also be related to the gender/ age specificities (Potvin \& Hasni, 2014; Walpner et al., 2016), or teaching science subjects within Estonian schools, separately, from grade 8 . Results also showed gender differences - girls were significantly more interested 
than boys in learning about plants and natural phenomena Boys were more eager to learn about atomic structure and electric circuits, but the overall interest in these topics was still low.

Within the motivation part, analysis identified five M-dimensions (intrinsic motivation, valuing science learning, effort, negative attitude and science subject), describing $73.3 \%$ of the variance. While the second (value) and the third (effort) dimensions overlapped with the subscales in the original instrument (Deci \& Ryan, 2015), the first (intrinsic motivation) and the fourth (negative attitude) included items from the interest/enjoyment, perceived competence and autonomy subscales. When comparing differences between boys and girls towards M-dimensions, it became evident that statistically significant differences appeared within two dimensions - girls were perceived to value, and put more effort into science learning than boys.

\section{Students' motivational profiles}

Taken into account four M-dimensions (intrinsic motivation, valuing science learning, effort and negative attitude), omitting science subject, K-means cluster analysis identified three clusters (with low, medium and high motivation rate of students) within each science (biology, earth science, chemistry and physics) subject, altogether 12 clusters. Clusters were identified subject-wise, because students answered to all motivational items within one science subject specifically. Clusters differentiated from each other both in size (incl. the number of boys and girls), as well as interest and the motivation to learn.

Results of the study showed a tendency for students with a higher motivation than other student clusters indicated a more positive satisfaction with school science. They were also interested in all topics offered, despite the context. At the same time, students in the low motivation subject related clusters were characterised by the lack of interest in scientific topics, regardless of the context, especially in physics and chemistry abstract topics. However, the average rate of motivation of students was characterised by rather low interest. Thus, based on the results of the current study, it is important to pay more attention to students who have low interest and motivation to learn science subjects, by including more context-based and studentcentred learning methods in order to arouse and maintain their interest. In general, the current study shows that students' interests are, on the one hand, subject specific and, on the other hand, students' interest are affected by their motivation level. 


\section{Conclusions}

1. Students' interest towards learning science topics depended on the context, as well as the science subject. Most students were interested in technological applications and natural phenomena presented in personal and social contexts. Abstract chemistry and physics topics were the most uninteresting for grade nine students. Based on the science subject, it can be concluded that plants in biology, and relief is earth science, were the topics perceived to be within students' interest, dependent on the context.

2. Gender differences emerged, both in the interest, as well as in the motivation, towards science learning. While biology and earth science related topics (plants and various natural phenomena) were significantly more interesting for girls, physics and chemistry related topics (e.g. atomic structure and circuitry) were statistically significantly more interesting for boys than girls. The motivation of girls and boys showed gender differences in the way that the girls were perceived to value and put significantly more effort into science learning than did the boys.

3. Based on the four M-dimensions, it was possible to distinguish, within each science subject, three profiles - high, medium and low motivation students who were differentiated by their contextual interests and motivation.

Based on the current research, it is suggested that science teachers should make more courageous use of personal and social contexts in teaching abstract (content-related) topics, thus increasing and holding interest. Further studies are needed to find out the differences in students' interests and motivation between different age groups (e.g. students from grade 6 and 9) and between students' and teachers' opinions on science learning contexts.

Keywords: interest, motivation, contexts in science learning, students' motivational profiles 